\title{
IMPLEMENTING FLIPPED CLASSROOM MODEL IN DEVELOPING BASIC LANGUAGE ARTS OF THE FOURTH GRADE STUDENTS
}

\author{
Dr. Mehmet Fatih KAYA \\ ORCID: 0000-0001-8494-8429 \\ Faculty of Education \\ Usak University \\ Usak, TURKEY
}

Received: 22/11/2020 Accepted: 17/03/2021

\begin{abstract}
This study aims to examine the role of the Flipped Classroom Model (FCM) in the development of the basic language skills of 4th grade students in Turkish language lesson. In this respect, in the 4th grade Turkish language lesson in which the FCM was used, the views of fourth-grade students, their teachers, and parents related to the circumstances and process occurred during the implementation of the FCM in improving the basic language skills of students were investigated. The study was designed in the action research. The study was conducted with thirteen activities in the fourth grade Turkish language lesson and lasted nine weeks and 45 course hours. Data were collected from observations, interviews, documents, action plans, learning materials and validation committee meeting decisions. According to results the activities carried out during the implementation contributed to the development of language skills of the students. It was also seemed that students' various cognitive, affective, psychomotor and social skills developed, that improvements happened in terms of classroom management, and that behavioral problems which affect the implementation process decreased. In addition, students, their teachers and parents were observed to have positive opinions regarding the FCM and the implementation process.
\end{abstract}

Keywords: Flipped Classroom Model, language arts, basic language skills, Turkish language teaching, mother tongue education, technology integration.

\section{INTRODUCTION}

Regarding the development of a country, focus is generally on education and economic development. However, the use of language is not mentioned (Zulfikar, 2011). Some mother language-related circumstances can be considered as the most important indicators of the development level of a country, such as the development of language skills of individuals living in the country, the ability to use their skills, vocabularies, expressing themselves, and in-depth understanding. Therefore, societies need people whose mother language has developed because individuals using mother tongue competently have mental competence in terms of healthier, richer, more critical and in-depth thinking skills (Karaduz, 2016).

While mother tongue education is a process that starts with the birth of the individual, this task is officially undertaken by the Turkish language lessons in school period. Accordingly, Turkish language lessons play a pioneering role in using students' receptive and expressive skills. Mother tongue includes listening, speaking, reading and writing skills. These skills are closely related, since in real life, they are not used separately but together (Brown, 2007). A development in one of the one of them affects other skills in that direction (Gunes, 2009; Demirel \& Sahinel, 2006). In this respect, it can be said that Turkish language lesson is the basis of other lessons and individuals who are not competent in their mother tongue will have difficulty in other lessons (Guneyli, 2007). Therefore, there is a significant relationship between Turkish language lesson (mother tongue lesson) and other lessons (Bloom 1995; Ural \& Ulper, 2013; Bayat, Sekercioglu \& Bakir, 2014; Sever, 2011; Ceran \& Deniz, 2015). In studies on this subject, although emphasis has been 
placed on education councils and curriculums prepared to date, it is observed that the students do not show sufficient success in national and international exams (Acar, 2012; Akbaba-Altun, 2009; Bozkurt, 2016). In this context the subject of Turkish instruction (mother tongue education, language arts education) emerges as one of the problems waiting to be solved at all levels.

Some problems mentioned are not considering the individual differences of the students, crowded classes, insufficient time for in-class activities and inadequate activities, low quality of textbooks, teachers' use of materials, their teaching methods and lack of knowledge and skills related to assessment, pre-service and in-service training (Taskaya \& Musta, 2008; Girmen, Kaya \& Bayrak, 2010; Demircan \& Inandi, 2008; Kirmizi \& Akkaya, 2009). It is noteworthy that there are quite a lot of grammar in the graduate theses in the field of Turkish instruction in the national framework. Studies on language skills are less compared to other subjects, especially in listening and speaking (Yagmur Sahin, Kana \& Varisoglu, 2013; Varisoglu, Sahin \& Goktas, 2013).

It can be claimed that e-learning will enrich the teaching of mother language thanks to the structure of e-learning processes, providing opportunities for multifaceted and interactive environments, addressing individual characteristics, facilitating learning, and creating a natural interaction environment (Ulas, 2002; Peregoy \& Boyle, 2012). E-learning environments, in the simplest sense, allow for multimedia that brings together of components such as text, graphics, sound and video in a computer environment and their digital presentation (Ongoz, Aydin \& Aksoy, 2016. Thus, multimedia; It is stated that, due to its structure, it can provide effective learning in terms of preparing the ground for participatory and active learning, appealing to different senses, facilitating learning, having a high level of interaction, being flexible and addressing individual differences (Katirci, 2010; Kilic, 2006; Rogers, 2001). Therefore, it can be thought that e-learning processes can enrich Turkish instruction.

Consequently, considering the place and importance of technology in terms of individuals and societies, it is natural to state that technology and language teaching should be brought together (Ozdemir, 2017). In order to make use of technology more systematic and planned, it is vital to include technology-based models, methods and techniques. Therefore, the FCM, which combines in-class and out-of-class teaching-learning processes in a complementary and systematic manner, is one of the models that have gained importance in recent years (Rossi, 2014; Tosun, 2017).

According to the FCM, the teaching-learning process is divided into two processes: in-class and out-of-class. In other words, the FCM systematically combines in-class and out-of-class teaching-learning processes in a supportive, complementary and cyclical way. Thus, the FCM turns the traditional learning experience on its head by asking students to do traditional in-class activities at home, and traditional homework activities at class. In this process the student watches the videos prepared by the teacher, takes notes, prepares questions and completes activities, and comes to school ready for learning preparedly. The teacher checks the student participation online. In the classroom, the teacher provides tasks and learning circumstances that are based on individual or group works in which students can put theory into practice and where they can join the process creatively (Bergmann \& Sams, 2012; Bergmann \& Sams, 2016; Lage, Platt \& Treglia, 2000). In the FCM, students can control their own learning process without time and space limitation in line with their individual differences, needs and speeds, while they are active and play a more interactive role with others in classroom activities (Carbaugh \& Doubet, 2015; O’Flaherty \& Philips, 2015) (Figure 1). 


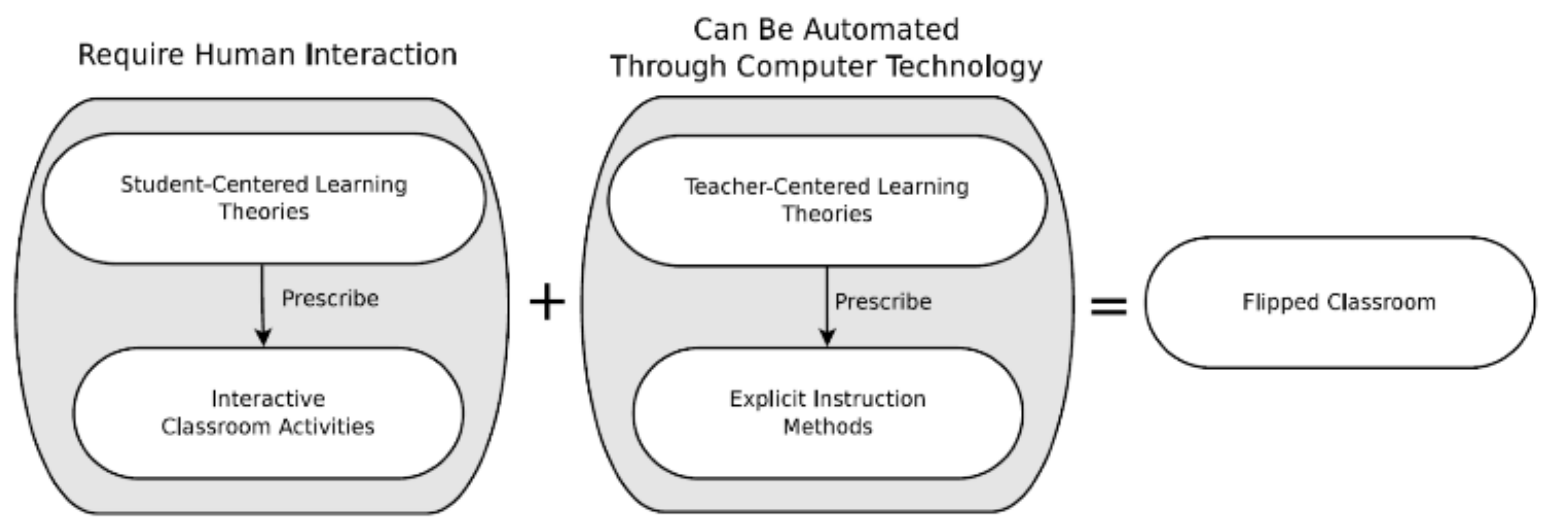

Figure 1. Flipped Classroom Model (Bishop \& Verleger, 2013, p. 6)

According to Flipped Learning Network (FLN, 2014), the FCM has four main components. The acronym "F-L-I-P" refers to the initials letters of the components: Flexible Environments, Learning Culture, Intentional Content and Professional Educator. Flexible Environments brings the process under control with the help of technology by taking the teaching-learning processes to the out of the classroom. Thus, on the one hand, there is a large and flexible virtual environment created by technology outside the classroom, while on the other hand a physical and wide flexible environment created by information and / or text-based content in the classroom occurs. Learning Culture includes behavioural systematic such as the education stakeholders know how, when, and in what type of activities the components of the process will act; they know which topic wil be taught and how to teach it; they know how a problem will be solved. Therefore, all the components of the class create a learning culture with its own characteristics and variables. Intentional Content includes various learning contents and materials prepared by educators to make the process more efficient depending on subject area and student's circumstances. Professional Educator is the most important component of the FCM. Even though professional educators seem to have fewer roles in the classroom, they are those who prepare and follow in-class and out-of-class teaching-learning processes, who observe students and follow their development, who provide immediate feedback and evaluate works.

\section{FCM AND BASIC LANGUAGE SKILLS}

Turkish (mother tongue) language lessons include studies based on reading text or listening; speaking and writing; verbal or nonverbal receptive and expressive language skills, studies based on relevant language skills and vocabulary, and studies based on teaching of grammar in terms of education level. Accordingly, Turkish language is a skill-based course since it aims to have students use their mother tongue effectively in their daily and future academic life.

The skill-based structure of the Turkish language lesson contains the processing of basic language skills, vocabulary and grammar based on a text (reading, listening, watching -such as film, animations and cartoons- text) related to the theme in primary school. Hence, the Turkish language lesson can be divided into various dimensions in terms of the FCM (i) reading, listening or watching the text; (ii) processes such as language arts, enrichment of vocabulary and teaching of grammar subjects. Thus, in a Turkish language lesson it may be appropriate to perform some activities based on the FCM at home such as reading, listening or watching a text, general superficial studies about language arts, instructional grammar content, superficial vocabulary studies and simple task such as research of subject content. At the same time, it may be appropriate to perform some activities such as activities related to the text and based on speaking and writing skills, practice-based activities related to grammar and vocabulary in-class. In addition, the teacher's ability to follow and monitor the student participation of homework activities before the class time, observe how much the subject/text is understood, use non-adaptive original formats of texts can contribute to the process of Turkish language teaching (Bergmann \& Sams, 2012, 2014). 
Considering the Turkish language lessons, since reading and listening take a lot of time, it can be said that in-class time can be quite broad. A great attention could be paid for speaking and writing skills that were neglected before due to lack of time (Pasisis, 2015). In this context, as the process of teaching Turkish language is not a one-dimensional knowledge and skill area but it includes multi-faceted and complex activities (Sever, 2011), it allows the use of texts of sufficient length in their original form that will develop the students' language awareness.

In addition to this, regarding texts or skills, there can be long-term group works, games, theatrical activities, visual and audio studies, and interdisciplinary studies (Gunes, 2012). Therefore, there is a need for models that effectively combine in-class and out-of-class processes during the process of Turkish language teaching -and the development of language skills. In this respect, the FCM has the potential to be applied in Turkish language lesson due to its nature. Thus, it can be assumed that students' language skills can be improved by using the FCM in Turkish language lesson.

\section{THE AIM OF THE STUDY}

There are many FCM-related studies conducted on various disciplines in different education levels. Literature generally provides studies on science and mathematics (Johansen \& Cherry-Paul, 2016). Considering language, researches have mainly focused on teaching a language as a foreign language (Basal, 2012; Ekmekci, 2017; Hung, 2015; Temizyurek \& Unlu, 2015). However, it can be said that there are few studies on mother language skills (Cockrum, 2017; Moran, 2014; Moran, 2018). Studies reveal that the FCM generally can play a role in the development of language skills (Basal, 2015). In addition, studies related to the FCM were usually conducted at university level and fewer studies can be found as the education level decreases (high, secondary or primary school levels) (Johansen \& Cherry-Paul, 2016). In this respect, it is important to conduct research on the primary school level.

Considering the problems, circumstances and potentials of the population, lesson and FCM, it can be said that there is a need for operational researches in which new technology assisted/based learning approaches are put into teaching-learning environments actively and in a qualified manner. In this context, for the Turkish language lesson, the use of the FCM was preferred in the research. Because it includes a process in which in-class and out-of-class teaching-learning environments are designed, technological tools are put to work, e-learning contents are prepared, student-teacher-parent interaction is ensured, and student development can be followed easily. With the use of the model in the process, it can be thought that the students' use of digital technologies in the learning process and the involvement of parents in the teaching-learning environment outside of the classroom will increase the student's motivation and thus success. Finally, the FCM can be used in different disciplines, contribute to various educational processes and development of language skills. Hence this study is developed based on the above reasons. So, the aim of this study is to examine the role of the FCM in the development of the basic language skills of 4th grade students in Turkish language lesson. In order to achieve this aim, the following research questions were asked:

- What are the situations related to the implementation of the FCM during the process of developing the basic language skills of the students in the 4th grade Turkish language lesson in which the model was used?

- What are the views of 4 th grade students, their teachers, and parents about the implementation of the FCM?

\section{METHOD}

The design of this study is action research. Considering education, action research refers to a systematic research which is conducted by the teacher-researchers, school principals, school counsellors or other stakeholders of the teaching and learning environment and in which the information is gathered to reveal how the school works, how teaching is done and how students learn better (Mills, 2003). Therefore, it can be said that the action research process is not only a "research" but also a broad activity process that includes "research, description, definition, improvement and development". The action research process has its own 
internal control system. In this respect, it refers to the process includes implementing the action plans, reviewing, correcting and reimplementing. This situation continues in a flexible and cyclical structure until it is saturated. In this way, it gives the researcher the opportunity to access all the details in the process.

Action research was utilized in this study, because it aims to define and describe the circumstances that occur during the process of improving the basic language skills of 4th grade students in Turkish language lesson via the FCM, and to find solutions to the possible problems during implementation. In this study, the action research method was preferred because instead of focusing on certain variables in the development of basic language skills, it was aimed to reach the relevant variables and structures by observing the natural environment of the process and examining it in depth.

The FCM-based action plans implemented during the action research process of this study consist of two dimensions: out-of-class learning processes that were defined as home activities and in-class learning processes. In the first dimension, out-of-class learning processes were conducted and managed through technological components. In this respect, it was seen necessary to prepare a website in which e-content was prepared in different formats (text, video, audio, visual) could be presented, student responses could be collected, and student participation could be followed. Therefore, instead of preparing a paid and specialized website, the researcher preferred creating a free website in which everyone could produce contents.

The e-content on the website was presented through Google Forms which required a Gmail account. The Google Forms interface is simple, straightforward and free from different stimuli, such as the student's logging into the activity, completing the content in the desired order, and finally logging out after sending the answers. Thus, in order to be suitable for the primary school students, a simple design was preferred. When the time came, the activities on the website were activated and the students were informed. The activity guidelines, structured diaries, texts, and contents prepared on Google Forms were presented on separate pages, and students were required to complete all the relevant sections to go to the next page.

In-class learning processes that constituted the second dimension of the action plans included activities such as in- class speeches, discussions, games, role plays and puppet theatre. While selecting the texts in accordance with the themes of Turkish language lesson, some features were taken into account, such as quality, diversity, content and use of language, compliance with the relevant age level, and diversity of Turkish and World Literature. It included different digital forms of the texts such as reading (written text, video reading text), monitoring (cartoon, documentary, digital story), listening (listening text in audio format) and visual (picture, cartoon, comic book). In text-based action plans, language skills, technological abundance (digital story) and manual skills (puppet and visual preparation) were used both together and separately.

These activities were organized as individual and group activities so that students could be active in the classroom. Individual or group products of the students such as posters, written texts, slogans, posters, pictures, digital stories, and digital products were collected and analyzed in each lesson and they were used as direct quotes to support the findings. In activities carried out every week, an attention was given to this diversity to attract students' attention and interest, increase their participation and prevent them from getting bored with the texts and activities. Thus, the variety of activities was considered to contribute positively to the students' development in different skill areas (Gerber, Cavallo \& Marek, 2001).

The researcher presented the prepared action plans, texts and website to the opinions of experts consisting of two associate professors specialized in Turkish language and classroom teaching and one assistant professor specialized in computer and teaching technology. Accordingly, necessary revisions were made in accordance with their feedback. Then, the researcher conducted a pilot study with the fourth grade students of a private school and a public school with a middle socioeconomic level. The pilot process includes 10-day pilot implementation process, and 30 lesson hours in-class observation before the actual implementation. In and after running the piloting and observation processes, the action plans were tested if the process and activities are appropriate for $4^{\text {th }}$ grade students and their living. According to the results, the action plans were revised. Also, it was aimed to determine the circumstances and problems of students' basic language skills and technology use in Turkish language lesson in terms of the FCM and research questions. Finally, the actual implementation process was carried out. Research permissions were obtained from Governorship, Directorate of National Education, school administration, teachers, students, and parents. 


\section{Process}

This study was conducted with 4th grade students (4/C class) in a state school in Eskisehir in the fall semester of 2016-2017 academic year and it lasted 9 weeks and 45 course hours. Every week, action plans were implemented and the data were collected in Turkish language lessons. Two semi-structured interviews were conducted with the students at the end of the second and ninth weeks. Parents were asked to write their views both in the middle and at end of the process. The parents were asked for their opinions about the students and the implication process on various topics such as the situations at home, fulfilling their duties, the details they reflect from school to home about the lesson and the process, the situations of doing homework. Because they observed the out-of-school life of the students. Two interviews were conducted with the teacher: the first one was before the application, focusing on the personal, family and academic status of the students while the second interview was at the end of the application and it was about the whole process. And the lessons were processed according to the action plans prepared by the researcher.

The validity committee, which was established in order to provide support for the implementations and contributions of action plans, problems encountered and solution suggestions, researcher and student behaviors during the implementation process, convened a total of four times every two weeks. In this process, lessons were taught according to action plans prepared by the researcher within the scope of the study and action plans were reviewed in line with the recommendations of the data and validity committee and classroom observations. The students' completing home activities was monitored independently of time and place; observations were done during in-class courses with camera; researcher and student wrote diaries; stakeholders (students, teachers and parents) were interviewed; students learning products were collected.

\section{Participants}

In this study, criterion sampling was applied. Criterion sampling takes the basis of studying all situations with various predetermined criteria (Yildirim \& Simsek, 2008). The criterion was that student needed to have at least one device (e.g. desktop, laptop, tablet computer, smartphone) and wired, wireless or mobile internet access at home. In this context the students used different devices in the process. Whether this difference affects the process has not been measured. Because no application, software or content requiring high level technical features were used. However, in case of technical problems of the students, the problems were solved in a short time by contacting the researcher instantly. The sample consisted of 23 fourth grade students (11 males and 12 females), their teacher and parents. The teacher of the class had a 22-year professional experience. As the researcher carried out the implementation process, the class teacher took an observer role. Sitting at the back of the classroom, he observed the lesson process and helped the researcher and made recommendations when necessary. So, the teacher was not trained about the use of the FCM. Most of the students had middle and upper-middle socioeconomic status. A male student in the class has an ADHD (attention deficit and hyperactivity disorder) report. According to the class teacher, another male student was younger than others, so he did not have the same level of development and characteristics, while two girls had learning difficulties. However, the researcher included these students in the study, as they were an element of the natural environment of the class and as he wanted to observe how these students were possibly affected from the implementation process. It was examined how the application in this heterogeneous class could bring about a process for different students.

\section{Data Collection Tools}

Action research requires multiple data collection methods since it is process-oriented and usually takes a long time to collect data for the focused problem (Yildirim \& Simsek, 2008). Thus, various data collection tools were utilized such as observations, interviews, documents (student diaries, researcher diary, and student products), action plans, learning materials and validation committee meeting decisions.

In the current work, the researcher took part as a participant observer. Since the researcher was not able to take field notes due to being a practitioner in the process, in-class applications were recorded with the help of video cameras in order to avoid data loss. After the lessons, in his diary, the researcher reflected his views, comments and feelings about the situations he encountered during the observation process. During the 
lessons, the researcher took notes and expanded his observations by comparing his diaries during the video casting. Within the study process, students kept diaries to reflect their feelings and thoughts about home activities, e-content presented in digital media, in-class activities. These feedbacks were collected every day as structured diaries through website.

Students' responses to digital texts, educational videos and e-learning contents at home activities in the digital learning environment were collected as student products during the process. In-class activities consisted of individual or group presentations such as writing works, poster, banner, visual creation, slogan, role play, drama, puppet theatre, digital story.

A validity committee was established in order to provide support to the researcher regarding some issuessuch as the feasibility and contribution of action plans in the study process, problems encountered and their solutions, and researcher and student behaviours. The committee consisted of one associate professor specialized in the field of Turkish language and classroom teaching, one associate professor specialized in the field of classroom teaching and action research, one associate professor specialized in the field of classroom teaching and Turkish language teaching, and one assistant professor specialized in the field of classroom teaching, qualitative research methods, and social studies. During the study process, validity committee meetings were held at approximately two-week intervals and a total of four meetings were held. During these meetings, the researcher took notes and recorded them as meeting decisions. After the studies, the researcher reviewed the action plans and carried out the implementation process.

The views of students, teachers and parents were interviewed in this study. Students were interviewed twice with using semi-structured interviews. Moreover, two semi-structured interviews were conducted with the teacher. Because reaching, visiting and interviewing with the 23 parents was so hard, written opinions were collected twice through open-ended questionnaires. The reason for this is to be able to follow and identify the status and problems of the implementation process with the opinions of different participant types, and at the same time, to apply their opinions in order to make necessary arrangements regarding the problematic parts. Semi-structured interviews were recorded via voice recorders and transferred to computer environment by the researcher. The data were then analysed using the Nvivo8 program. The researcher consulted with an associate professor and an assistant professor (specialized in the field of basic education, Turkish language teaching, qualitative research methods, action research and educational sciences) for semistructured interview forms and open-ended questionnaires. Necessary revisions were in line with experts' feedback and a semi-structured interview was piloted with three students. Questions were examined in terms of intelligibility and the possible problems were determined. Then, as a final step, the researcher made the necessary revisions and submitted the forms to the validity committee.

\section{Data Analysis}

Content analysis was used to analyse the data obtained from the interviews of students, their teacher and parents. Content analysis is based on the processing of information that a particular message covers and carries (Bilgin, 2006). The starting point is shaped according to the purpose of the research. In the content analysis, at first the categories are created, then the data are coded according to these categories (Elo \& Kyngas, 2008). In this context, interviews were transcribed and new categories and codes emerged by the help of Nvivo8 program. Then, the researcher classified the direct quotations according to categories and codes and interpreted the data.

Descriptive analysis was used to analyse the data collected from observations, students products, diaries, and researcher notes. The data of the descriptive analysis are summarized and interpreted according to the previously determined themes. Direct quotations are included to conspicuously reflect the views of the individuals interviewed or observed. The following stages are followed within the scope of descriptive analysis: creating a framework for descriptive analysis, processing data according to thematic framework, defining the findings, and interpreting the findings (Yildirim \& Simsek, 2008). Accordingly, the data were classified according to the circumstances and problems affecting language skills and the development of language skills and the related notes were taken. 
In this study, the data collected were arranged in a meaningful and logical holistic way. For example, in a puppet theatre event that included stages of writing and presenting the text, the process of students' writing the text (writing, punctuation, use of story items) was handled under the skill of writing while the presentation phase (the prepared puppet, tone of voice, use of visual elements) was handled under the skill of visual presentation. Direct quotations from observations, interviews, student products, and student and researcher diaries were used to support the findings of the study. Furthermore, the data were defined and explained in a reader friendly way.

\section{Validity, Reliability and Ethics}

In qualitative research, credibility (accuracy, dependability) refers to observing and transmitting data as neutral as possible (Kirk \& Miller, 1986). Transferability (confirmability) means that similar situations can be experienced rather than generalizing the findings and results to other situations (Yildirim \& Simsek, 2008). In this study, necessary permits were obtained from institutions, students, teachers and parents. The views of the validity committee and field experts were consulted for the action plans, interview forms, e-learning contents and the suitability of the materials, and the necessary revisions were made in line with the recommendations. The researcher tried to guarantee data diversity by gathering data from different sources while the data were investigated by the researchers separately in order to ensure researcher diversity. The data were presented to the validity committee that met at regular intervals and their expert opinions were obtained. Thus, the reliability of the study was aimed to be high. To help the readers visualize the research context in mind, detailed descriptions and direct quotations are included in the presentation of the findings regarding the transferability of the study. Therefore, it can be said that the results of this research are applicable in the classes with the same or better conditions. In this context, the aim was to increase the level of transferability of the study.

In addition, it was cared protecting the physical, mental health and happiness of the participants, and ensuring the conformity of the research with ethical values in terms of scientificity in the study. In this context, (i) necessary official permissions for the research environment and participants were obtained. (ii) Participants (students, parents and classroom teacher) were informed about the research and written and verbal consent was obtained that they voluntarily participated in the research. (iii) The participant information was hidden in the presentation of the findings, the faces were blurred in the images and the nicknames were used instead of the real names. (iv) The data were shared with the participants and interested parties when necessary. (v) Research data was used only in this research. As a result, it can be claimed that the researcher behaved within the ethical rules during the research and conducted the research in accordance with the ethical rules.

\section{FINDINGS}

\section{Findings Related to Basic Language Skills}

Considering the themes included in the curriculum, 13 activities based on the FCM were implemented. The texts used in this framework are prepared in different genres (fairy tales, stories, cartoons, animated films, poems) and digital formats (reading text, listening text, video). Additionally, the instructional contents were presented by videotaping. It was aimed to improve basic language skills in a holistic manner during the activities and the activities were designed to address multiple language skills. Vocabulary and grammar were developed in various ways during activities. During activities, some other cognitive, affective, dynamic, social and technology skills as well as language skills were developed. 
Table 1. Activity A: Dede Korkut

\begin{tabular}{|c|c|c|c|c|}
\hline \multirow{4}{*}{ 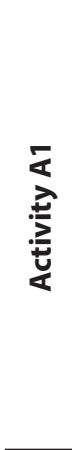 } & 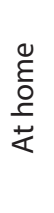 & $\begin{array}{l}\overline{0} \\
\text { О } \\
\stackrel{0}{0} \\
0 \\
0 \\
0 \\
0 \\
1 \\
1\end{array}$ & Preparation & $\begin{array}{l}\text { - Students were asked to watch the first chapter of the cartoon (Dede Korkut } \\
\text { Stories). https://www.youtube.com/watch?v=CCEHsOpXqHk } \\
\text { - Then, students were asked to answer text-based questions }\end{array}$ \\
\hline & $\overline{0}$ & ¿ & Introduction & $\begin{array}{l}\text { - Students talked about the videos they watched, and their thoughts were } \\
\text { collected. }\end{array}$ \\
\hline & 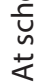 & $\underset{\sqcup}{0}$ & $\begin{array}{l}\text { Teaching-learning } \\
\text { process }\end{array}$ & $\begin{array}{l}\text { - Students were divided into two groups and asked to write their predictions } \\
\text { about the continuation of the story. }\end{array}$ \\
\hline & & & Evaluation & - Student writings were evaluated. \\
\hline \multirow{6}{*}{ 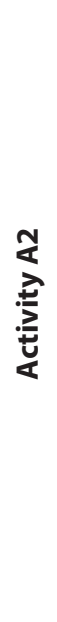 } & 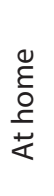 & 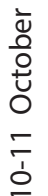 & Preparation & $\begin{array}{l}\text { - Students were asked to watch the other selected chapters of the cartoon } \\
\text { (Dede Korkut Stories). https://www.youtube.com/watch?v=VFKVtngWXiU } \\
\text { - They were asked to note the words they did not know. }\end{array}$ \\
\hline & \multirow{5}{*}{ 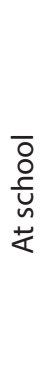 } & \multirow{5}{*}{ 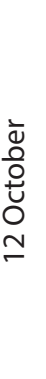 } & Introduction & $\begin{array}{l}\text { - Students talked about the videos they watched and their thoughts were } \\
\text { applied. }\end{array}$ \\
\hline & & & & - Students were asked the words they did not know. \\
\hline & & & $\begin{array}{l}\text { Teaching-learning } \\
\text { process }\end{array}$ & $\begin{array}{l}\text { - Students were informed about how to search the meaning of the words } \\
\text { from the Turkish Language Institution website and what to look for when } \\
\text { searching information on the Internet }\end{array}$ \\
\hline & & & Evaluation & $\begin{array}{l}\text { - Students were asked to determine the values in the text and to write } \\
\text { outcomes from the text about these values. }\end{array}$ \\
\hline & & & & - There was a writing slogan activity related to the subject. \\
\hline
\end{tabular}

Students' skills in using technology, accessing reliable and accurate information, and using secure internet were developed through digital media, which is the other pillar of the FCM and in which the home activities were completed. Moreover, after each activity, students' views about the activity, text and / or contents used were asked. Thus, problems in the process of action research were minimized. An example of the implementation plan of an activity can be seen in Table 1 .

Table 2, presents the contents of all the activities, the type and digital format of texts used, what was done during the activity process, and related language skills. In Table 2, it is seen that the students' multiple language skills were developed. In addition to the language skills, improvement was observed in various outcomes, such as social, technology use, imagination, discussion, estimation and appreciation. For example, as the activity progresses, it was noted that; the capability to use language skills was developed (Activity K); the quality and quantity of texts were improved in writing skills (Activity J, K). In terms of speaking skills, the fear of speaking in public decreased while responsibility and motivation increased (Activity L, M); qualifications, subject matter and remarkable contents were handled considering visual presentation (selfexpression with visual), imagination, creativity (Activity H, K). Also, there were developments in theatrical skills (Activity M); and also learning increased and misuses reduced in grammar. In addition, considering working culture and group work, it was seen that the students worked in harmony, that the quality and quantity characteristics of the products improved, that skills such as not disturbing others improved, and that problematic behaviours decreased in group writing, product creation or game-based activities (Activity E, H, K, N) (Appendix 1). Related examples are presented in Appendix 1. 
Table 2. Contents of all activities

\begin{tabular}{|c|c|c|c|c|c|}
\hline $\begin{array}{l}\text { Name of } \\
\text { Activity }\end{array}$ & Text type & $\begin{array}{l}\text { Content } \\
\text { format }\end{array}$ & $\begin{array}{l}\text { Activity content, what has been } \\
\text { done }\end{array}$ & $\begin{array}{l}\text { Group/ } \\
\text { individual }\end{array}$ & Related language skills \\
\hline Activity A & Cartoon, Saga & Video & $\begin{array}{l}\text { Group writing, vocabulary, } \\
\text { understanding and analysis of text, } \\
\text { slogan writing, visual creation, } \\
\text { reliable sources of information and } \\
\text { internet usage }\end{array}$ & $\begin{array}{l}\text { Group, } \\
\text { Individual }\end{array}$ & $\begin{array}{l}\text { Monitoring, speaking, } \\
\text { writing, vocabulary, } \\
\text { grammar }\end{array}$ \\
\hline Activity B & Story & Listening & $\begin{array}{l}\text { Writing a title for text, } \\
\text { understanding and analysis of } \\
\text { text, visual creation and written } \\
\text { expression of visual, puzzle }\end{array}$ & Individual & $\begin{array}{l}\text { Listening, writing, } \\
\text { vocabulary, visual } \\
\text { presentation }\end{array}$ \\
\hline Activity C & Tale & Reading & $\begin{array}{l}\text { Predicting content by image, } \\
\text { understanding text and vocabulary } \\
\text { studies, role playing (writing and } \\
\text { presenting), playing games }\end{array}$ & Group & $\begin{array}{l}\text { Reading, visual } \\
\text { reading, writing, visual } \\
\text { presentation, speaking }\end{array}$ \\
\hline Activity D & Theatre & Video & $\begin{array}{l}\text { Understanding and analysing text, } \\
\text { writing texts, puppet theatre }\end{array}$ & Group & $\begin{array}{l}\text { Visual reading and } \\
\text { presentation, monitoring, } \\
\text { writing, speech }\end{array}$ \\
\hline Activity $\mathrm{E}$ & $\begin{array}{l}\text { Instructional } \\
\text { content }\end{array}$ & Video & $\begin{array}{l}\text { Instructional content, reinforcing } \\
\text { the topic }\end{array}$ & Individual & Language and meaning \\
\hline Activity F & Tale & Listening & $\begin{array}{l}\text { Understanding and analysing } \\
\text { text, writing, speaking, visual } \\
\text { presentation, digital story } \\
\text { preparation, vocabulary }\end{array}$ & Individual & $\begin{array}{l}\text { Listening, writing, } \\
\text { speaking, visual } \\
\text { presentation, vocabulary }\end{array}$ \\
\hline Activity G & $\begin{array}{l}\text { Instructional } \\
\text { content }\end{array}$ & Video & $\begin{array}{l}\text { Instructional content, reinforcing } \\
\text { the topic, playing game }\end{array}$ & Individual & Grammar \\
\hline Activity $\mathrm{H}$ & Comic book & Reading & $\begin{array}{l}\text { Reading, understanding and } \\
\text { analysing text, writing, visual } \\
\text { presentation }\end{array}$ & Group & $\begin{array}{l}\text { Reading, writing, visual } \\
\text { presentation }\end{array}$ \\
\hline Activity J & $\begin{array}{l}\text { Animation } \\
\text { movie }\end{array}$ & Video & $\begin{array}{l}\text { Monitoring, understanding and } \\
\text { analysing text, cup game (preparing } \\
\text { songs) }\end{array}$ & $\begin{array}{l}\text { Group, } \\
\text { Individual }\end{array}$ & $\begin{array}{l}\text { Monitoring, auditory } \\
\text { presentation, writing }\end{array}$ \\
\hline Activity K & $\begin{array}{l}\text { Story, } \\
\text { instructional } \\
\text { content }\end{array}$ & Listening & $\begin{array}{l}\text { Listening, understanding and } \\
\text { analysing text, instructional } \\
\text { content, reinforcing the topic, visual } \\
\text { creation and written expression }\end{array}$ & Individual & $\begin{array}{l}\text { Listening, visual } \\
\text { presentation, grammar }\end{array}$ \\
\hline Activity L & Documentary & Video & $\begin{array}{l}\text { Monitoring, vocabulary, } \\
\text { understanding and analysing } \\
\text { text, national park creation and } \\
\text { presentation, researching and } \\
\text { writing, peer review }\end{array}$ & Group & $\begin{array}{l}\text { Monitoring, vocabulary, } \\
\text { visual presentation, } \\
\text { writing, speaking }\end{array}$ \\
\hline Activity M & $\begin{array}{l}\text { Animation, } \\
\text { instructional } \\
\text { content }\end{array}$ & Video & $\begin{array}{l}\text { Monitoring, grammar, } \\
\text { understanding and analysing } \\
\text { text, drama, reliable sources of } \\
\text { information and internet usage }\end{array}$ & $\begin{array}{l}\text { Individual } \\
\text { Group }\end{array}$ & $\begin{array}{l}\text { Monitoring, grammar, } \\
\text { visual presentation, } \\
\text { technology literacy }\end{array}$ \\
\hline Activity N & $\begin{array}{l}\text { Instructional } \\
\text { content }\end{array}$ & Video & $\begin{array}{l}\text { Instructional content, reinforcing } \\
\text { the topic, playing game }\end{array}$ & Group & Grammar \\
\hline
\end{tabular}

\section{Views of Participants}

\section{Views of Parents}

The researcher used two written form procedures in order to gather the views of the parents who observed their children during out-of-school processes. The first form was filled by 19 parents, while the second form was completed by 20 parents. The researcher analysed data using content analysis. Data from both interviews were combined to be presented under various codes and categories here (Figure 2). It was seen that all parents (except one) had positive views of the FCM. Thus, it can be stated that the FCM served the purpose for contributing to students from different perspectives, creating positive attitudes towards Turkish language lesson, providing effective use of technology, and handling the term "doing homework" in a different way. 


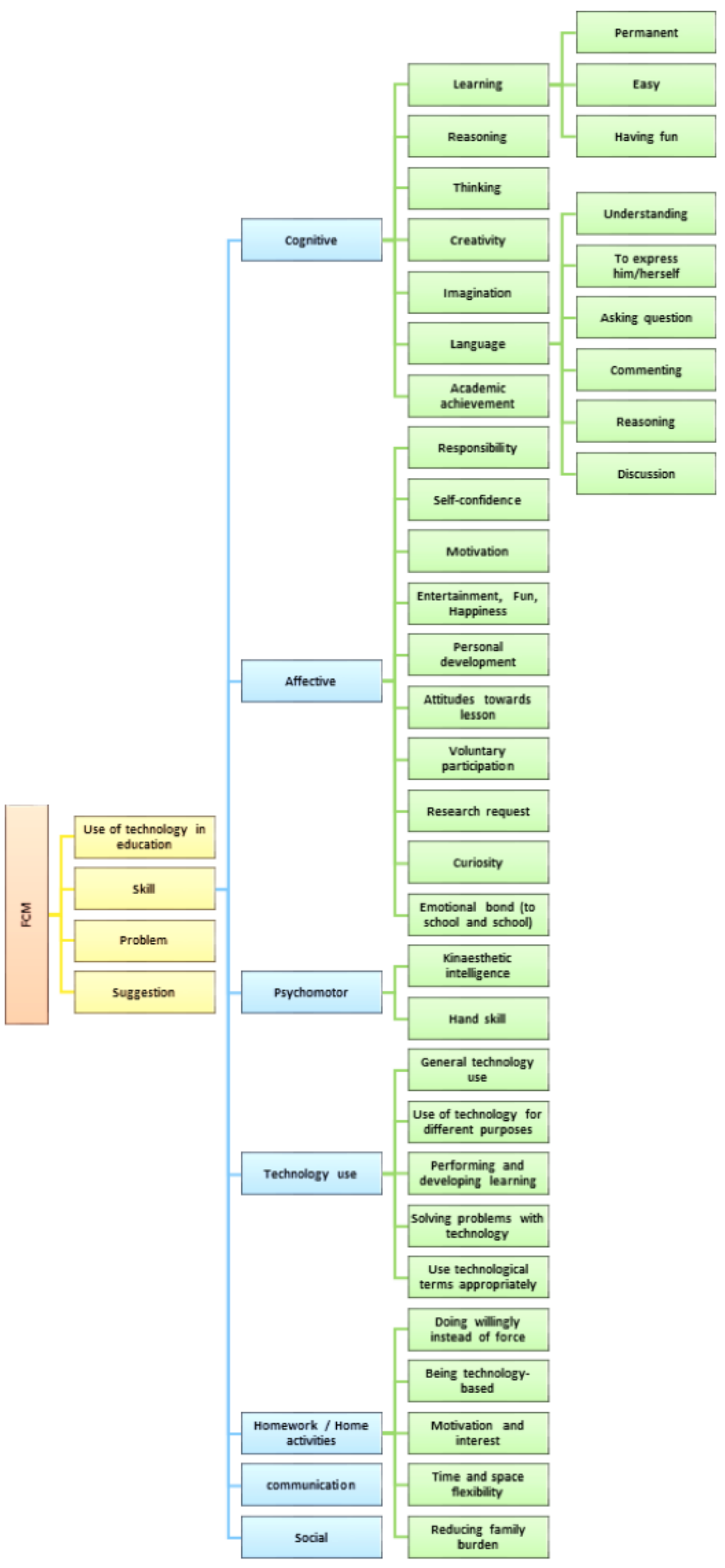

Figure 2. Codes and categories obtained from the views of parents 
Considering the use of technology in education, parents stated that children's use of technology enhanced, that children had a useful and effective time with technology, and that the use of technology in education would be beneficial even for parents. Almost all of the parents approved the positive effects of the FCM-based activities on students. In addition, it was emphasized that students' cognitive, affective, dynamic, language-communication, social, group work, and technology use skills developed; that there became changes in their behaviours in school, family and social life; that the rate of their participation in classroom activities and homework increased. In addition, parents of students in the disadvantaged group stated that the social skills and behaviours of their children developed as they were often with friends and they partly got over their introversion.

Considering the home activities that were the pillars of the FCM, parents indicated that the students (who did not use to do homework, who did not want to do it, and who pretexted for not doing it) did their homework willingly and entertaining entertainingly without getting bored anymore; that technology motivated students to do their homework; that students could do their homework at home, on the road, in the park as technology provides opportunities to study independent from time and place; and that it also contributed to the students in the disadvantaged group.

Beren: During the activities at home, I have observed that my daughter is trying to understand what she is watching. She is trying to watch it over and over again and comment on the subject. When we watch the activities together, she finds errors in my comments. In a nutshell, she can see what she looks at, she can understand what she sees, she can question what she understands, she can express what she questions.

Dilek (disadvantaged): We observe positive changes in school, family and social life. She communicates more easily in her dialogues in the family. She uses words and sentences better. While doing homework, she understands the questions. She has a better communication with her friends.

Eda: Thanks to this implementation, homework has turned into fun rather than being considered as duty or responsibility. She does homework without getting bored and feeling under pressure. The use of tablet or phone makes life quite easy because using tablet and earphones reduces the working pressure helps students enjoy the homework since it makes it possible to do homework on the road and in the park... To sum up, I am of the opinion that your effort to teach lesson in a play and entertainment environment provides success for my daughter and my family.

Elcin: First of all, she enjoys the activities you give in the course. She's looking forward to being in your lessons. Every new activity you share arouses my daughter's curiosity. My daughter is happy as she does not have to do desk-based. She does responsibilities with a "great pleasure", instead of considering it as a "must".

Erhan: When I and my son evaluate in-class and home activities, he indicates that they are permanent, effective, and full of fun... I believe that this new approach and methods will provide higher efficiency in education. I think it is a training model that makes the student active and realize what they have learned... In contrast to the monotone lessons, my son both learns and develops what he learns and makes the learning permanent for life thanks to this implementation. He is willing to do the activities instead of considering it as a must. He explores and develops many skills, including technology, imagination, and many verballinguistic- kinaesthetic intelligences. He can express himself comfortably as his self-confidence increased in social life... Now, we are optimistic towards computers and mobile phones. This implementation has even changed our attitudes towards technology (the Internet, computer)

Gokalp: Although my son is a child doing his homework all the time, he becomes more willing to do the lessons with technology. He loves your activities very much and wants to complete them immediately. At the beginning of the process, I used to believe that he would have used your lessons as a means of playing Internet games. I checked him many times to learn whether he plays games or does activities. I always found him studying. His interest of Internet games lessened. He has become more harmonious at home. No pressure and restrictions. You have educated us too. He is more willing to go to school. I wish all lessons were conducted in this way, neither would children be bored from school nor we would have problems. Can you offer this model to the Ministry of National Education for all courses?

Tarik: Thanks to activities, we have observed various positive features of this implementation, such as the ability to search, develop, and use technology in a positive way; being able to approach the problems positively; the ability to be patient; finding an answer in his own effort; desire and excitement to investigate... He used to ask us for help, but now he himself searches and finds. Last but not least, his self-confidence increased. 
In addition to the above positive opinions, only one participant (Metin's parent) expressed a negative opinion. He stated that there was no change in student behaviours; that it did not contribute to his motivation; that the model did not work, and that he considered the activities given by the researchers as "work load".

Metin: Considering the behaviours of my son, the model seems useless. He just had to do some of his assignments via internet and computer, which didn't seem to be very productive, but I don't have any data on learning outcomes. Technical problems made the job more difficult. He started to use the computer more and he had to spend more time on homework.

\section{Views of Students}

During the research process, two semi-structured interviews were conducted with the students. The first interview incudes 18 students while the second one was actualized with 22 students. The researcher analysed data using content analysis. Data from both interviews were combined to be presented under various codes and categories here (Figure 3).

The students stressed that they were generally positive about the FCM-based implementation process, that it led to learning by having fun and improved their language skills, that it was better than the traditional teacher-student instruction, that it increased students' attitudes towards school and lesson, and that it fostered academic development and learning. In terms of doing activities and homework, according to students, the time spent with technology became very useful, doing homework became easier, they did not get bored while doing homework, and the model increased their willingness to do homework.

According to the views of the students, the FCM-based activities provided various outcomes in terms of cognitive, affective, and psychomotor skills. In addition, the students generally liked activities based on group work (theatre, presentation, visual preparation, play).

Students preferred group works for various reasons such as job sharing, sharing ideas, creating more ideas, faster and more products, longer and qualified writing effective decision-making, increased happiness and respect and cooperation, easy solving problems, and the nice and fun side of working together. In addition, the students stated that they had difficulty in some activities such as writing text, making shapes with dummy and play dough, role preparation and role-play, and group work.

Arda: I have become successful in my lessons and my grades have increased. My ability in reading comprehension, writing and grammar have improved. I used to have difficulty in writing text. Now I can write... Not only do we learn how to use technology but also we learn Turkish by having fun.

Ayca: I was always watching Youtube. These activities are more fun than watching the ridiculous things. I was getting excited and I was wondering what your activity would be when I went home... Homework is not workload anymore.

Batuhan: My listening, speaking and understanding have improved, and it has also contributed to my math ability. I couldn't make problems before, but now I'm doing well. I didn't use to love Turkish lesson much, but now I love it... We feel happy, we respect each other and we get everyone's opinions.

Beren: My handicraft and technology use skills have developed.

Ecrin: I had diffculty in making puppets.

Erhan: Sometimes I couldn't think due to noise. The group work worked well. Because sharing and correcting ideas is more appropriate for me rather than working by myself. I'm getting more successful.

Nihal: I had so much fun and would love to do it all the time. It has been developing intelligence. My imagination and thoughts are improving.

Tarik: Sometimes I had difficulty in writing theatre text and acting.

Yesim: My computer use has improved. I could only play games before. Now I'm more comfortable with computers, I can do more. The activities are full of fun and better than the traditional lessons. 


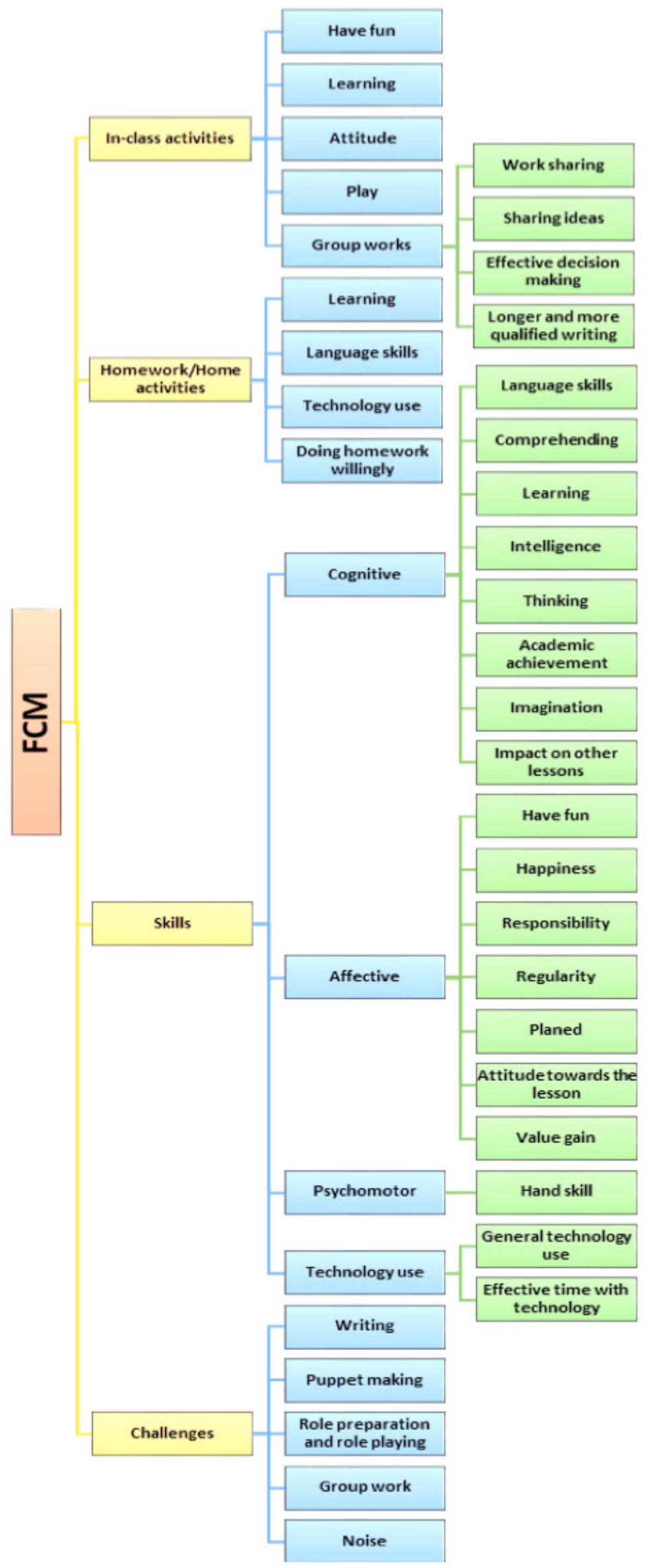

Figure 3. Codes and categories obtained from the views of students 


\section{Views of the Teacher}

At the end of the study, a semi-structured interview was conducted with the classroom teacher who was an observer in the classroom. The researcher analysed data using content analysis. Data were combined to be presented under various codes and categories here (Figure 4).

The teacher talked on the use of technology in the implementation process. He thinks that he and his parents are convinced that technology can be used in education. The teacher also has positive views about the FCM. He stated that the model could be used in many courses, that e-contents were successful, and that students came class preparedly owing to the use of in-class and out-of-class processes in a complementary manner, that they were willing to do activities as they loved the process and the researcher, and that they have adopted the model.

The teacher indicated that the texts, e-contents, activities presented during the application process were suitable for the student level. In addition, he stated that some outcomes (academic achievement, language skills, learning subjects, self-confidence) were achieved and some learning problems were overcome. Finally, the teacher stated that such models and applications could be used by disseminating technology-based educational projects and appropriate e-learning content at primary level.

"At the beginning, we had some shortcomings in terms of technology. After getting to know the process, both parents and we have witnessed how computers have been used in education. We all have to let children use the computer for educational purposes. The applicability of the model is quite high, so it is successful. I think it can contribute to the change in education in basic courses. Activities were nice. When the students watched them at home, they came to school preparedly and did not get tired... They loved the applications and you (the reseacher) as well. Therefore, they have adopted the method... Activities and texts were suitable for students. They understood some topics well. Thanks to group works and presentations, their speaking in front of public skill was developed. Even children who did not attend classes developed self-confidence. We observed good outcomes."

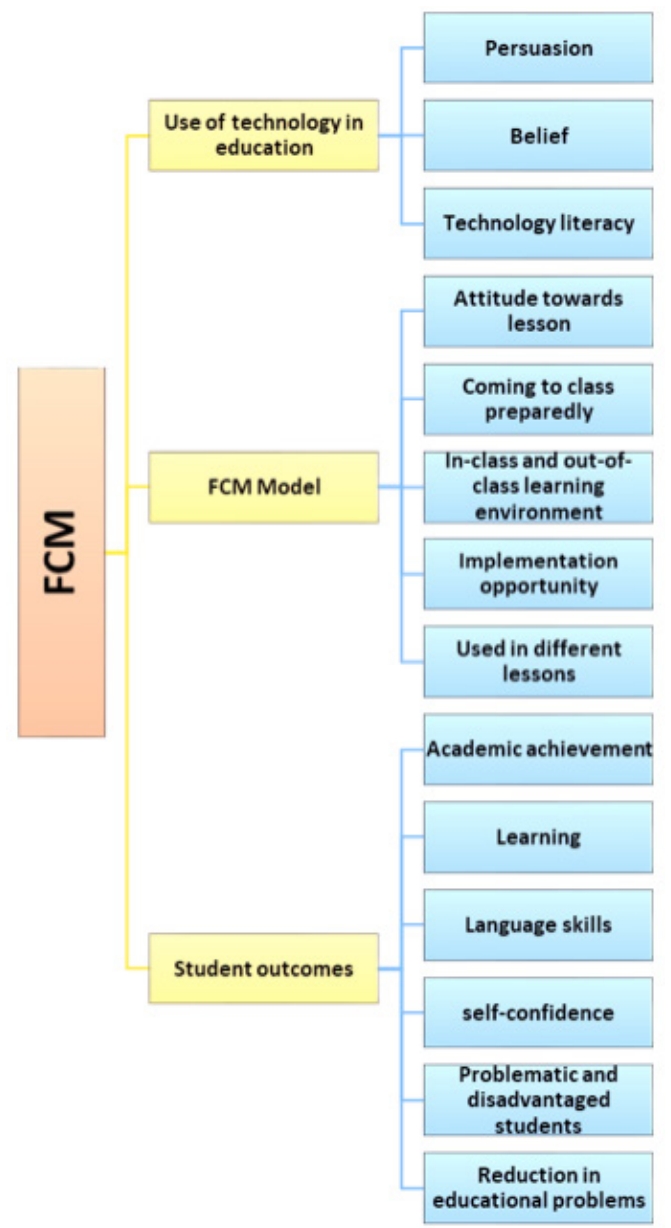

Figure 4. Codes and categories obtained from the views of the teacher 


\section{Findings Related to the Process of the Flipped Classroom Model}

In this study, the focus was on the whole components of the process as much as possible, rather than focusing only on some aspects of the teaching-learning process. Thus, it has been tried to create an effective teachinglearning environment, culture and process. In the context of the second research question, the process was examined in depth. With the help of multiple data collection methods and tools, various situations that affect the development of basic language skills in classroom and out-of-class processes have been reached. In this framework, since the natural environment of the process was observed, there was no case of controlling different variables. Within this framework, various codes and categories related to FCM implementation process have been reached (Figure 5).

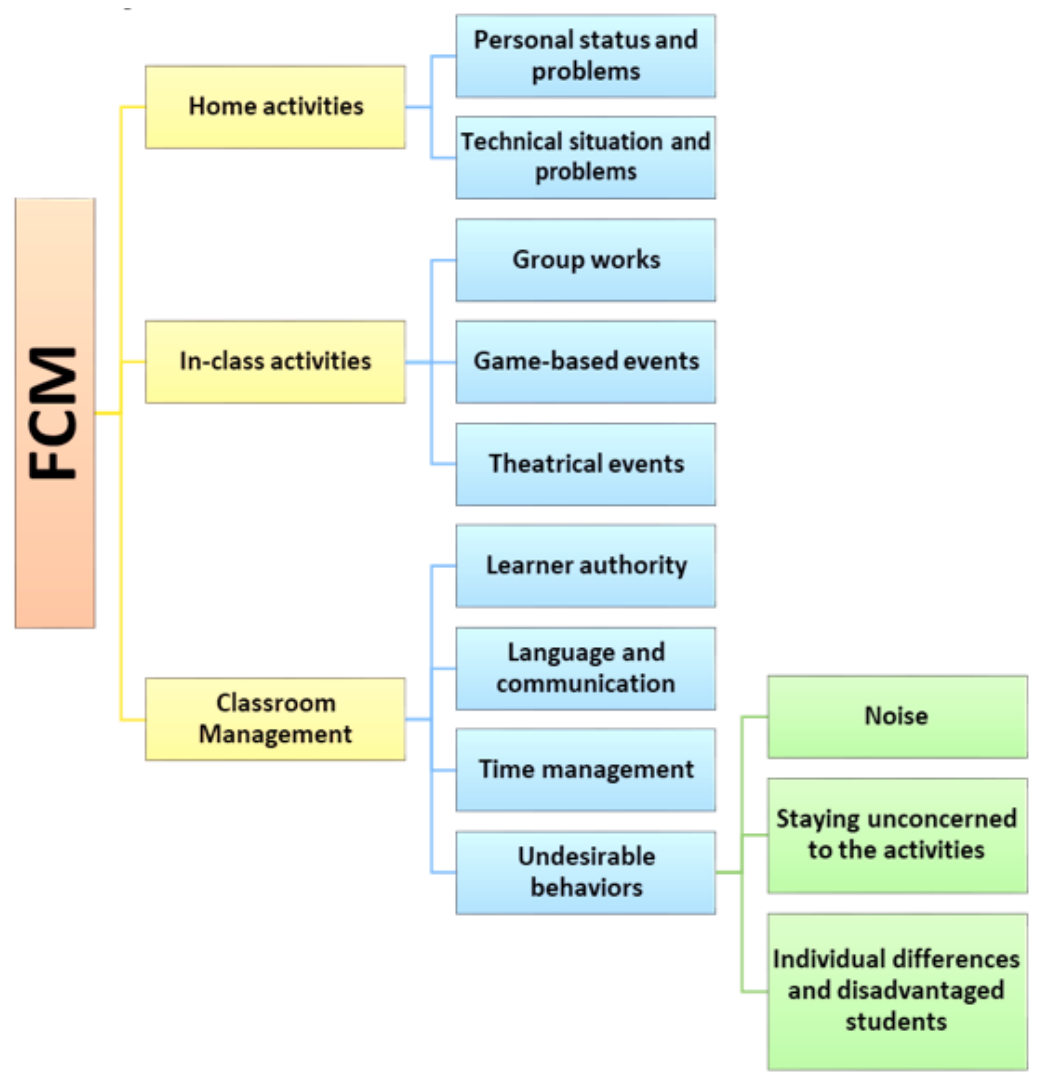

Figure 5. Findings related to the process of the Flipped Classroom Model

\section{Home Activities}

Home activities refer to the completion of e-learning content and activities within the times and/or environments apart from the school and/or course hours with the help of technological components. These processes include technical and technological infrastructure (hardware, software, website or platform), e-learning contents (text, video, audio, visual), collection of responses, and participant follow-up.

In general, the level of student participation in home activities was noted to be low at the beginning, but it started to increase later. Thus, considering home activities, the number of participants joining activities $\mathrm{A}$, $\mathrm{B}, \mathrm{C}$ and $\mathrm{D}$ was between 14 and 18 while the whole class ( 23 students) participated in Activity E. The mean of all activities was 20 students.

Some disadvantaged students had participation problems. Especially, Ozan who had the ADHD report participated in almost half of the home activities. Although the teacher contacted his family several times (e.g. Activity H), his participation was not at the desired level. In the process, some students could not participate in their home activities due to technical and technological problems. Accordingly, technological problems (such as internet outage, devices and their versions, lack of necessary applications and programs) negatively affected the students' participation in home activities. 
Thanks to the home activities, there were activities in which the students could learn, reinforce and repeat the subjects during the classroom period. At the same time, a great attention was paid to different enriching activities such as individual or group works, games, theatre, drama, preparing visuals, and visual and auditory presentations.

They were mind-empowering, thought-provoking, cooperative, educational, instructive, exciting, enjoyable and fun activities that generally made students active, increased their participation, interest, attention and motivation (e.g. Activity H, J, K, L). In such activities, students did not go out of class even during breaks (e.g. Activity $\mathrm{H})$. As an example, students were watched a promotional video of a "National Park" in Turkey as home activity and asked them to answer some questions about the video. In class activities, students' questions were answered, and the text was discussed. Then they were given various materials and asked to create their own national parks. Here, the students were asked to prepare a text to introduce their national parks and to do research on the plants and animals living in their national park. The students worked in groups of two. In this process, the students discussed with their group friends about what kind of national park they should create, shared their tasks and made research. At last, they made their parks together on cardboard with various cutting and gluing works. Eventually they gave a presentation to other students introducing their national parks (Appendix 1). In addition, the students in the audience position of the presentations were given an evaluation form and they were asked to evaluate the presenter group. At the end of the activity, the students stated that not only their language skills but also their thinking, research and hand skills, group work, imagination and creativity improved.

In addition to the language skills, improvement was observed in various outcomes, such as social, technology use, imagination, discussion, estimation and appreciation. For example, as the activity progresses, it was noted that; the capability to use language skills was developed (Activity K); the quality and quantity of texts were improved in writing skills (Activity J, K). In terms of speaking skills, the fear of speaking in public decreased while responsibility and motivation increased (Activity L, M); qualifications, subject matter and remarkable contents were handled considering visual presentation (self-expression with visual), imagination, creativity (Activity H, K). Also, there were developments in theatrical skills (Activity M); and also learning increased and misuses reduced in grammar. In addition, considering working culture and group work, it was seen that the students worked in harmony, that the quality and quantity characteristics of the products improved, that skills such as not disturbing others improved, and that problematic behaviours decreased in group writing, product creation or game-based activities (Activity E, H, K, N) (Appendix 1).

Classroom management influenced the implementation process in which intensive interactive activities were performed. Sometimes undesirable behaviours, noise, irrelevant behaviours of some students, time management, technical problems, and individual characteristics of students or being in a disadvantaged group made classroom management difficult. On the contrary, using positive communication language, thanking students, honouring and supporting them had a positive impact on classroom management. In this way, it was observed that the problems started to decrease after the second week (e.g. Activity D and E) and almost disappeared in the next activities (see Activity K). The problems of some disadvantageous student gradually decreased or disappeared. For example, there was an increase in the participation and product qualifications of Asli who had learning difficulties and focusing problems and who become distracted in lessons (e.g. Activity E and F). Nevin, -who was shy and had learning difficulties, who did not participate in activities, who almost never even spoke- played an active role, especially, in speech-based activities (presentation, digital story). Tarik, who used to be problematic, started to participate in the activities and an improvement was observed in terms of his behaviours, the quality of the products he prepared, his self-confidence, interest and attitude, academic achievement, and language skills (e.g. Activity E and M). Thus, it was observed that a learning culture was gradually formed in the classroom.

\section{CONCLUSION, DISCUSSION AND RECOMMENDATIONS}

This study aims to examine the role of the FCM in the development of the basic language skills of 4th grade students in Turkish language lesson and the the views of participants related to the process. The results displayed positive and important outcomes in terms of the applicability of the model in the Turkish language lesson with 4th grade students of a school with middle socio-economic level. 
Although the selected sample was a classroom where almost no technology was used previously, in the process and at the end of the study, student expressed positive views (Wang et al., 2019) which can be interpreted that the hesitations about the use of technology in education have been eliminated. Therefore, if the teacher -who is in direct contact with the students and parents- has the self-confidence and self-efficacy perception of technology integration, and if the teacher can use various methods, applications, techniques, technology, and developments effectively in the teaching-learning process, it can be claimed that the teacher can change the perspectives of other stakeholders and bring success (academic, belief, attitude) (Bayrak \& Hirca, 2016; Oral, 2008).

Unlike the traditional teaching-learning process, students have achieved various outcomes as this model has remarkable, interesting, motivational, entertaining, instructive, and multidisciplinary activities that formed rich experiences for language skills; that were based on individual and group works; that requires movement, interaction and participation; that were based on learner authority, self paced, flexible, independent working and learning environment, individualizing the learning content (Baepler, Walker \& Driessen, 2014; Bishop $\&$ Verleger, 2013; Moran \& Young, 2015). It means that a practice-based learning environment was provided for the students to learn by doing (Bosner, Pickert \& Stibane, 2015).

In the process, it has been observed that the students have the courage to express themselves effectively in various ways (writing, presentation, discussion, visual, banner, theatre, drama) and to carry out their works that are difficult to do with self-confidence. Some studies have parallel results (Ahmad, 2016; Ekmekci, 2017; Girmen \& Kaya, 2019; Mo \& Mao, 2017; Ozdemir \& Acik, 2019; Turan \& Akdag-Cimen, 2019; Awidi \& Paynter, 2019). As students were given a plenty of time in activities, activities (such as producing ideas, designing the product, preparing and explaining when necessary) contributed to the development of students' skills and creativity while enabling them to work freely and produce products. Therefore, it can be said that the FCM formed a student-centred and effective learning environment. These results are in parallel with the studies in the related literature (EARGED, 2007; Gould, 2007; Kardas \& Uca, 2016; Kardas \& Ozturk, 2015; Gocer \& Garip, 2020; Tunagur, Kardas \& Kardas, 2021).

At the end of this study, it was seen that the FCM had important opportunities for Turkish language lesson. It can be said that significant developments can be seen in students' language and other related skills when the in-class and out-of-class activities are structured and maintained. During the implementation process, activities based on individual or group works, games and theatre activities were included. These activities enhanced the efficiency of the FCM by enriching the implementation process (Girmen \& Kaya, 2019). In this regard, it is stated in the related literature that such activities contribute positively to the various skills by activating students and increasing their participation (Enfield, 2013; Gilboy, Heinerichs \& Pazzaglia, 2015; Talan \& Gulsecen, 2019); they contribute students' academic development (Cheng, Ritzhaupt \& Antonenko, 2019; Karagol \& Esen, 2019); their permanent and in-depth learning (Gogebakan-Yildiz, Kiyici \& Altintas, 2016; Danker, 2015; Gasmi, 2016); development of language, communication and social skills (Samuel, 2019); development of various cognitive skills like metacognitive awareness, critical, creative, reflective high level thinking skills (Danker, 2015; Hwang, Yin, \& Chu, 2019; Kong, 2014; Carpenter, 2016; Chen, Hwang \& Chang, 2019), affective skills like taking responsibility and self-efficacy (Bond, 2019; Lai \& Hwang, 2016), and psychomotor skills like some fine hand skills, using technological devices (Huang \& Hong, 2016); working with peers; their decision-making skills; and respect each other's ideas (Sonnenwald \& Li, 2003; Millis, 2010; Michaelsen, Davidson \& Major, 2014; Akandere, 2013; Akoz \& Toptas, 2009; Karakaya, 2007; Kavak \& Koseoglu, 2007; Ulubey \& Toraman, 2015; Akar Vural \& Somers, 2011). In addition, such activities facilitate student-centeredness and differentiated teaching (Fulton, 2014) and develop authentic learning based on role-playing, real-life experiences and discovering (Murphy, 2009; Elbistanli, 2015).

Language lessons differ from other courses as they require texts to improve language skills. Instructional contents are used in the teaching of language rules. In this context, only reading and a small amount of listening texts are presented in the traditional teaching-learning process. However, since only reading or listening to texts takes a lot of time in the classroom, there is not enough time left to conduct activities for language skills (Kirmizi \& Akkaya, 2009; Taskaya \& Musta, 2008). Since reading / listening and preparing texts is done outside the classroom, in-class time is expanding and various activities can be made easily. According to this, effective time management can be ensured in FCM process (Bergmann \& Sams, 2012). 
The diversity of text types (fairy tales, stories, cartoons, poems), the sources (Turkish and world literature) and the way it was presented (reading text in digital media, listening text in $\mathrm{mp} 3$ format, comics, animation films, documentaries) strengthened the process of the FCM in this study. Thus, increasing the students' curiosity and interest level, individual differences were considered. These results are supported by literature (Sahin \& Bayramoglu, 2016; Asici, 1997; Cecen \& Ciftci, 2007; Cakir, 2013).

As frequently performing activities that require movement, interaction and participation during the implementation process reduces classroom management problems, effective time management actualised and the activities were conducted as planned. Thus, the in-class activities turned into processes that were learned by having fun; that provided learning and participation motivation by arousing curiosity and attention; that enhanced emotional bond with school, lessons and teachers (Alamri, 2019; Galvez, 2017; Awidi \& Paynter, 2019; Chien \& Hsieh, 2018; Danker, 2015; Gogebakan-Yildiz, Kiyici \& Altintas, 2016; Aycicek \& Yanpar Yelken, 2018). In this context, teachers can ensure the completion of the teaching-learning process with maximum benefit by planning extended, longer-lasting interdisciplinary activities with the mother language lessons. Therefore, the relationship between the mother language lessons and other lessons (Bloom, 1995; Taskaya \& Musta, 2008; Albayrak \& Erkal, 2003; Guneyli et al. 2010) shows that the study of language skills in other courses will not be a waste of time.

During the implementation of the FCM, parental participation is of paramount importance, especially in terms of observing out-of-class activities. Therefore, thanks to activities that bring the student and family together, the effective involvement of families in the process positively influenced the views of students and families, and provided the families with a one-to-one observation environment. The fact that parents had a chance to observe the process of the FCM closely is one of the reasons why the participants had positive views about the model and process. So, in the process of the FCM, family involvement can be ensured (Bond, 2019).

According to the results, the FCM shows parallelism with various learning theories, teaching-learning approaches and various findings (Fulton, 2014; Chang, 2016). As seen in results, the FCM has a very close relationship with learner-centred education and effective learning. In this context, learner-centered education approach is associated with many concepts such as flexible learning, self-directed learning and experiential learning. Therefore, multidimensionality comes to the fore in student-centered application processes. (O’Neill \& McMahon, 2005).

In order to realize student centeredness, While the teacher facilitates the students to structure the information in the application processes, the student acts as the person who is active in the learning process, makes choices according to their own needs, and thus is responsible for their own learning (Lea, Stephenson \& Troy, 2003; Burnard, 1999). In this way, student-centered education offers students the opportunity to effectively manage their own learning processes (Acat, 2005). The students who were freed in home activities, by taking their own learning responsibilities, realized their own learning within in-class activities and in individual and group activities. The role of the teacher in the process has been in the position of facilitating learning, guiding the student, helping them think and produce ideas. In this respect, student development was reflected in their behaviours and attitudes, products and opinions. Beside that it can be said that the process of the FCM helps student be what Maslow called "self-actualizing individual"; that it provides students with the opportunity to achieve high-level skills in the Bloom taxonomy; that it is intertwined with almost all concepts of constructivist paradigm: that it is related to Vygostky's "zone of proximal development"; that it coincides with Piaget's cognitive research and concepts; that it is parallel with the concepts and views of Dewey, Bruner and Ausubel on education (Ornstein \& Hunkins, 2016). Therefore, it is seen that the FCM serves many thoughts, theories, models and approaches regarding "learning" by planning the implementation process well.

It can be seen that the implementation process served all of the basic components of the FCM (FLN, 2014). In other words, those students worked in a digital environment without time and space limit in the home activities and that they worked on various activities based on individual and group activities in classroom activities was related to the "Flexible Environments" component. The teaching-learning process, which was formed by the characteristics of the application process, was based on "Learning Culture" component. Diversifying the texts and activities used in the process was about "Intentional Content" component. Finally, 
the researcher's playing a role in the process (in terms of planning, implementation, teaching, classroom management, identifying and intervening problems, monitoring process and development) served the "Professional Educator" component. Therefore, it can be said that the study process has been completed in accordance with the FCM.

It should be kept in mind that there may be various limitations of the model. Each of the planning, preparation, implementation and evaluation stages passes intensively. The most important challenges faced in this research process were preparing the Internet environment; monitoring the participation and development of students; technical support and instant communication; data storage in digital media; selecting texts; designing, preparing, digitizing, editing and adapting e-learning content; providing diversity of activities and content; preparing student-centred and active learning-based activities; and producing solutions to problems by observing the process. Situations such as time, space, technological opportunities, low technology acquisition and usage levels of students, the familiarization period of the students at the beginning of the application process, embracing the systematic of the model, and participation and classroom management negatively affected the implementation process of the model. These situations are in parallel with the limitations encountered in the literature (Balci, 2017; Bergmann \& Sams, 2012, 2016; Girmen \& Kaya, 2019; Bergmann, Sams \& Gudenrath, 2014; Durak Uguten \& Balci, 2017; Filiz, Orhan-Goksun \& Kurt, 2016; Saitta et al., 2016; Turan \& Goktas, 2015; Yuan \& Moran, 2018). However, it can be said that the learning culture in the classroom that was formed by ensuring the continuity of student-centred and active learning-based activities eliminated many negativities and limitations.

As a result, it can be said that the FCM-based teaching-learning process, conducted in accordance with the Turkish Curriculum, has been successful. It can be thought that this situation will lead to the success of the curriculum, make students to keep up with the requirements of the digital age, and help students acquire 21st century skills. Therefore, teaching-learning environments based on the FCM should be enriched with supportive contents and activities together with technology supported models, methods and techniques. At this point, all stakeholders, especially teachers, should take responsibility in the process

According to the results, some suggestions related to implementation for practitioners of the educational processes can be presented. In parallel with this study, in terms the implementation of the FCM in Turkish language lesson, it is suitable to do comprehension-based works (reading, listening, watching of the text) at home while it is appropriate to do in-depth studies on the text as well as studies related to speaking and writing skills in the classroom. In addition, the effectiveness of the model may increase if the teacher monitors the student participation in home activities and observe whether the text is comprehended before attending the classroom. Beside that individual/group works based on effective learning and student-centeredness as well as a variety of interdisciplinary activities need to be applied in order to help students use their all language skills as well as high-level thinking skills and gain as much language experience as possible. Effective participation of disadvantaged students should be supported in this process.

Along with the FCM, the Turkish language lesson can include versatile, multidimensional, long-term individual and group studies, games, theatrical activities, audiovisual studies and interdisciplinary studies.

In order to enhance students' all language skills, higher level thinking skills, and to gain as much language experience as possible, some studies based on student-centered can be planned such as individual and group works, active learning activities, high participation and interaction activities, individual differentiated and interdisciplinary studies. However, it may be useful to have alternative activity plans, such as worksheets or individual activity plans, to avoid problems related to participation in activities that may result from individual differences or the characteristics of students in the disadvantaged group. In addition, some problems regarding classroom management can be seen in this process. Situations such as approaching students positively and constructively, doing activities that require participation, increasing participation in activities, frequently playing games, and using technology actively can be helpful in preventing many problems. In this way, economics can be achieved in time management and time usage.

The texts to be used must be in different digital formats. Providing diversity in visual or auditory contents such as reading/listening texts, videos, visuals, cartoons, animations, short films, news avoids boredom of students and addresses their curiosity, interest, imagination and individual differences. 
It is important for the teachers, who have the role of the FCM to plan the implementation process, prepare, implement and evaluate their content, to be professional trainers required by the model. In this respect, the process should start with the teacher training process. Starting from the undergraduate period, the pre-service teachers and the teachers who are working must be trained in the process about technology integration, technology supported teaching methods and their adaptation to the related course.

By supporting the active participation of students in the disadvantaged group in activities and lessons, academic and social development of these students can be achieved.

In out-of-school learning processes, some activities and contents that students can complete with their families could be designed. Thus, because of students' participation and satisfaction level, it will be ensured that the activities performed in the teaching-learning process are accepted by the families.

According to the results, some suggestions for researchers can be presented. In parallel with this study, further studies can be conducted (i) with students and schools at different socioeconomic levels, (ii) at different levels of education, (iii) in different lessons, and (iv) with different research designs.

Author's Note: The study is a part of a doctoral dissertation of "Mehmet Fatih Kaya" titled "Implementing Flipped Classroom Model in Developing Basic Language Arts of 4th Grade Students", and supported by Eskisehir Osmangazi University Scientific Research Projects Commission coded as "201621A211".

\section{BIODATA and CONTACT ADDRESSES of AUTHOR}

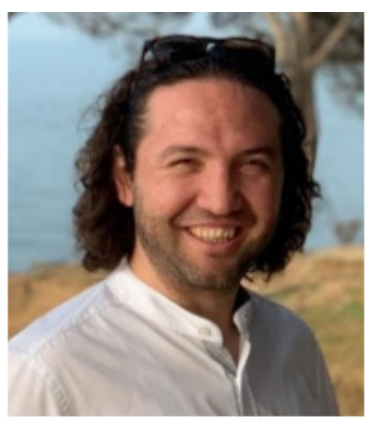

Dr. Mehmet Fatih KAYA is a Research Assistant of Curriculum and Instruction, Department of Educational Sciences at Faculty of Education, Usak University.

He undertook undergraduate studies (2005-2009) and gained master degree (2012) in the field of Primary School Teaching. He gained his Ph.D. in Curriculum and Instruction at June 2018. His academic interest areas are Flipped Classroom Model, ICT in education specifically primary level, mother tongue and language skills instruction,

Dr. Mehmet Fatih KAYA

Curriculum and Instruction, Department of Educational Sciences, Faculty of Education

Address: Usak University, 64000, Usak, Turkey

Phone: +902762212130

E-mail:mfatih.kaya@usak.edu.tr

\section{REFERENCES}

Acar, T. (2012). Turkiye'nin PISA 2009 sonuclarina gore OECD'ye uye ve aday ulkeler arasindaki yeri. Kuram ve Uygulamada Egitim Bilimleri, 12(4), 2561-2572.

Acat, M. B. (2005) Ogrenci merkezli egitimde ogrenme ortami boyutlarinin duzenlenmesi. V. Uluslararasi Egitim Teknolojileri Sempozyumu, Sakarya: Sakarya Universitesi.

Ahmad, S. Z. (2016). The flipped classroom model to develop Egyptian EFL students' listening comprehension. English Language Teaching, 9(9), 166-178.

Akandere, M. (2013). Egitici okul oyunlari. Ankara: Nobel.

Akar Vural, R. \& Somers, J. W. (2011). Humanist ilkogretim programlari icin ilkogretimde drama: Kuram ve uygulama. Ankara: Pegem.

Akbaba-Altun, S. (2009). Ilkogretim ogrencilerinin akademik basarisizliklarina iliskin veli, ogretmen ve ogrenci goruslerinin incelenmesi. Ilkogretim Online, 8(2), 567-586. 
Akoz, Y. \& Toptas, B. (2009). Ilkogretim 4. sinif ogrencilerinin Turkce dersinde ogrendigi kelimelerin anlamlarinin karsiliginin zihinsel olarak kavrama duzeylerinin incelenmesi. VIII. Ulusal Sinif Ogretmenligi Egitimi Sempozyumu. Eskisehir: Eskisehir Osmangazi Universitesi Egitim Fakultesi.

Alamri, M. M. (2019). Students' academic achievement performance and satisfaction in a flipped classroom in Saudi Arabia. International Journal of Technology Enhanced Learning, 11(1), 103-119.

Albayrak, M., \& Erkal, M. (2003). Basariya giden yolda ifade ve beceri derslerinin (Turkce-Matematik) birlikteligi. Milli Egitim Dergisi, 158.

Asici, M. (1997). Turkce ogretiminde metin ve metin incelenmesi. Istanbul: Eyuboglu Egitim Kurumlari.

Awidi, I. T., \& Paynter, M. (2019). The impact of a flipped classroom approach on student learning experience. Computers \& Education, 128, 269-283.

Aycicek, B., \& Yanpar Yelken, T. (2018). The Effect of Flipped Classroom Model on students' classroom engagement in teaching English. International Journal of Instruction, 11(2), 385-398. https://doi. org/10.12973/iji.2018.11226a.

Baepler, P., Walker, J. D., \& Driessen, M. (2014). It is not about seat time: Blending, flipping, and efficiency in active learning classrooms. Computers \& Education, 78, 227-236.

Balci, O. (2017). An investigation of the relationship between language learning strategies and learning styles in Turkish freshman students. English Language Teaching, 10(4), 53-61. DOI: https://doi. org/10.5539/elt.v10n4p53.

Basal, A. (2012). The use of flipped classroom in foreign language teaching. The 3rd Black Sea ELT Conference "Technology: A Bridge to Language Learning", November 15-17, 2012, Samsun.

Basal, A. (2015). The implementation of a Flipped Classroom in foreign language teaching. Turkish Online Journal of Distance Education, 16(4), 28-37.

Bayat, N., Sekercioglu, G. \& Bakir, S. (2014). Okudugunu anlama ve fen basarisi arasindaki iliskinin belirlenmesi. Egitim ve Bilim, 39(176).

Bayrak, N., \& Hirca, N. (2016). FATIH Projesi hizmetici egitimine katilan ogretmenlerin tekno-pedagojik ozyeterliklerinin incelenmesi. Gazi Universitesi Gazi Egitim Fakultesi Dergisi, 36(1). 95-111.

Bergmann, J. \& Sams, A. (2012). Flip your classroom: Reach every student in every class every day. Washington, DC: International Society for Technology in Education.

Bergmann, J. \& Sams, A. (2014). Flipped learning: Gateway to student engagement. International Society for Technology in Education.

Bergmann, J. \& Sams, A. (2016). Flipped learning for elementary intruction. International Society for Technology in Education.

Bergmann, J., Sams, A. \& Gudenrath, A. (2014). Flipped learning for English intruction. International Society for Technology in Education.

Bilgin, N. (2006). Sosyal bilimlerde icerik analizi: Teknikler ve ornek calismalar. Ankara: Siyasal.

Bishop, J. L., \& Verleger, M. A. (2013). The flipped classroom: A survey of the research. In ASEE National Conference Proceedings, Atlanta, GA.

Blair, E., Maharaj, C., \& Primus, S. (2016). Performance and perception in the flipped classroom. Education and Information Technologies, 21(6), 1465-1482.

Bloom, B. S. (1995). Insan nitelikleri ve okulda ogrenme (Cev. D. A. Ozcelik). Ankara: Milli Egitim.

Bond, M. (2019), Flipped learning and parent engagement in secondary schools: A South Australian case study. British Journal of Educational Technology, 50(3), 1294-1319. https://doi.org/10.1111/ bjet. 12765 .

Bosner, S., Pickert, J., \& Stibane, T. (2015). Teaching differential diagnosis in primary care using an inverted classroom approach: Student satisfaction and gain in skills and knowledge. BMC medical education, 15(1), 1 . 
Bozkurt, B. U. (2016). Turkiye'de okuma egitiminin karnesi: PISA olceginden cikarimlar. Abant Izzet Baysal Universitesi Egitim Fakultesi Dergisi, 16(4), 1673-1686.

Brown, H. D. (2007). Teaching by principles: An interactive approach to language pedagogy. New York: Longman.

Burnard, P. (1999). Carl Rogers and postmodernism: Challenged in nursing and health sciences. Nursing and Health Sciences, 1, 241-247.

Cakir, P. (2013). Turkce ders kitaplarindaki oykulerin cocuga gorelik ilkesi acisindan incelenmesi. Turkish Studies, 8(1), 1171-1180.

Carbaugh, E. M., \& Doubet, K. J. (2015). The differentiated flipped classroom: A practical guide to digital learning. Thousand Oaks, CA: Corwin.

Carpenter, R. (2016). Flipping the creativity class: Creating active-learning environments for student innovations. In Best Practices for Flipping the College Classroom (J. B. Waldrop \& M. A. Bowdon, Eds.) (pp. 118-130). Routledge.

Cecen, M. A. \& Ciftci, O. (2007). Ilkogretim 6. sinif Turkce ders kitaplarinda yer alan metinlerin tur ve tema acisindan incelenmesi. Millî Egitim, 173, 39-42.

Ceran, D. \& Deniz, K. (2015). TEOG sinavi sorularinin okuma becerisiyle cozulebilme duzeyi. Ana Dili Egitimi Dergisi, 3(2), 92-109.

Chang, S. H. (2016). The marriage of Constructivism and Flipped Learning. Indiana University Southeast. http://files.eric.ed.gov/fulltext/ED565608.pdf.

Chen, M. A., Hwang, G., \& Chang, Y. (2019), A reflective thinking-promoting approach to enhancing graduate students' flipped learning engagement, participation behaviors, reflective thinking and project learning outcomes. British Journal Educational Technology, 50, 2288-2307. https://doi. org/10.1111/bjet.12823.

Cheng, L., Ritzhaupt, A. D., \& Antonenko, P. (2019). Effects of the flipped classroom instructional strategy on students' learning outcomes: A meta-analysis. Educational Technology Research and Development, 67(4), 793-824. https://doi.org/10.1007/s11423-018-9633-7.

Chien, C. F., \& Hsieh, L. H. C. (2018). Exploring university students' achievement, motivation, and receptivity of Flipped Learning in an Engineering Mathematics Course. International Journal of Online Pedagogy and Course Design (IJOPCD), 8(4), 22-37. https://doi.org/10.4018/ IJOPCD.2018100102.

Cockrum, T. (2017). Emerging models of practice in Flipped English language arts classrooms. In Applying the Flipped Classroom Model to English Language Arts Education (C. A. Young \& C. M. Moran, Eds.) (pp. 160-176). IGI Global.

Danker, B. (2015). Using Flipped Classroom approach to explore deep learning in large classrooms. IAFOR Journal of Education, 3(1), 171-186.

Demircan, C. \& Inandi, Y. (2008). Koy Enstituleri programlarinda anadilinin onemi ve Turkce ogretimi. Mersin Universitesi Egitim Fakultesi Dergisi, 4(1), 1-13.

Demirel, O. \& Sahinel, M. (2006). Turkce ve sinif ogretmenleri icin Turkce ogretimi. Ankara: Pegem A.

Durak Uguten, S. \& Balci, O. (2017). Flipped learning. Journal of Suleyman Demirel University Institute of Social Sciences, 1(26), 253-265.

EARGED (2007). Ogrenci merkezli egitim uygulama modeli. Ankara: MEB.

Ekmekci, E. (2017). The Flipped writing classroom in Turkish EFL context: A comparative study on a new model. Turkish Online Journal of Distance Education, 18(2), 151-167.

Elbistanli A. (2015). Otantik ogrenme (Ed. A. Ari). Alternatif ogrenme ogretme yaklasim ve yontemleri icinde 85-98. Konya: Egitim.

Elo, S. \& Kyngas, H. (2008). The qualitative content analysis process. Journal of Advanced Nursing, 62(1), 107-115. https://doi.org/10.1111/j.1365-2648.2007.04569.x. 
Enfield, J. (2013). Looking at the impact of the flipped classroom model of instruction on undergraduate multimedia students at CSUN. Techtrends: Linking Research \& Practice To Improve Learning, 57(6), $14-27$.

Filiz, O., Orhan-Goksun, D. ve Kurt, A. A. (2016). Yuksekogretimde Donusturulmus Siniflar: Ozel Ogretim Yontemleri dersi ornegi. Egitim Teknolojileri Okumalari (Ed. A. Isman, H. F. Odabasi ve B. Akkoyunlu) icinde, 615-632.

Flipped Learning Network (2014). https://flippedlearning.org/definition-of-flipped-learning/

Fulton, K.P. (2014). Time for learning: Top 10 reasons why flipping the classroom can change education.Corwin.

Galvez, H. (2017). Flipped instruction for language learning. In Flipped Instruction: Breakthroughs in Research and Practice (pp. 131-144). IGI Global.

Gasmi, A. A. (2016). An exploratory study of students' lived experiences in a blended-flipped writing class. Arab World English Journal, 3, 210-226.

Gerber, B. L., Cavallo, A. M. L. \& Marek, E. A. (2001). Relationships among informal learning environments, teaching procedures and scientific reasoning ability. International Journal of Science Education, 23(5), 535- 549.

Gilboy, M. B., Heinerichs, S. \& Pazzaglia, G. (2015). Enhancing student engagement using the flipped classroom. Journal of Nutrition Education and Behavior, 47(1), 109-114. https://doi.org/10.1016/j. jneb.2014.08.008.

Girmen, P., Kaya, M. F. \& Bayrak, E. (2010). Turkce egitimi alaninda yasanan sorunlarin lisansustu tezlere dayali olarak belirlenmesi. 9. Ulusal Sinif Ogretmenligi Egitimi Sempozyumu, 20-22 Mayis 2010, Elazig, s. 133-138.

Gocer, A , Garip, S . (2020). Turkce Dersi Sosyal Etkilesime Dayali Sinif Ortamlarinin Ogrencilerin Anlatma Becerilerinin Gelistirilmesindeki Yeri. Adnan Menderes Universitesi Sosyal Bilimler Enstitusu Dergisi , 7 (2) , 16-32 . Retrieved from https://dergipark.org.tr/en/pub/adusobed/issue/58668/730199.

Gogebakan-Yildiz, D., Kiyici, G., \& Altintas, G. (2016). Ters-yuz edilmis sinif modelinin ogretmen adaylarinin erisileri ve gorusleri acisindan incelenmesi. Sakarya University Journal of Education, 6(3), 186-200. http://dx.doi.org/10.19126/suje.281368.

Gould, J. S. (2007). Dil becerilerinin ogrenimi ve ogretimine olusturmaci bir perspektif. (S. Durmus, Cev. Ed.) Yapilandirmacilikta Teori Perspektifler ve Uygulama icinde s. 111-123. Ankara: Nobel.

Gunes, F. (2009). Turkce ogretiminde gunumuz gelismeleri ve Yapilandirici Yaklasim. Mustafa Kemal Universitesi Sosyal Bilimler Enstitusu Dergisi, 6(11), 1-21.

Gunes, F. (2012). Testlerden etkinliklere Turkce ogretimi. Dil ve Edebiyat Egitimi Dergisi, 1(1), 31-42.

Guneyli, A. (2007). Etkin ogrenme yaklasiminin anadili egitiminde okuma ve yazma becerilerini gelistirmeye etkisi, (Yayinlanmamis Doktora Tezi), Ankara Universitesi, Ankara.

Guneyli, A., Ozder, H., Konedrali, G., \& Arsan, N. (2010). Ilkogretim ogrencilerinin Turkce ile diger ders basarilari arasindaki iliski. Akdeniz Egitim Arastirmalari Dergisi Mediterranean Journal of Educational Research, 123, 60.

Huang, Y.N., \& Hong, Z.R. (2016). The effects of a flipped English classroom intervention on students' information and communication technology and English reading comprehension. Educational Technology Research and Development, 64(2), 175-193.

Hung, H. T. (2015) Flipping the classroom for English language learners to foster active learning, Computer Assisted Language Learning, 28(1), 81-96.

Hwang, G. J., Yin, C., \& Chu, H. C. (2019). The era of flipped learning: promoting active learning and higher order thinking with innovative flipped learning strategies and supporting systems. Interactive Learning Environments, 27(8), 991-994. https://doi.org/10.1080/10494820.2019.1667150. 
Johansen, D. \& Cherry-Paul, S. (2016). Flip your writing workshop: A blended learning approach. Portsmouth, NH, Heinemann Educ., Books.

Karaduz, A. (2016). Elestirel paradigma ve dil ogretimi (A. Karaduz, Ed.). Elestirel dil becerileri: Kuram ve uygulama icinde s. 1-34. Ankara: Pegem.

Karagol, I., \& Esen, E. (2019). The effect of flipped learning approach on academic achievement: A metaanalysis study. Hacettepe University Journal of Education, 34(3), 708-727. https://doi.org/10.16986/ HUJE.2018046755.

Karakaya, N. (2007). Ilkogretimde drama ve ornek bir uygulama. Gazi Universitesi Gazi Egitim Fakultesi Dergisi, 27(1), 103-139.

Kardas, M. N. \& Uca, N. (2016). Aktif ogrenme yontemi-nin kullanildigi calismalarin ogrenci basarisi, tutumu ve gorusleri acisindan incelenmesi: Bir Meta-analiz Calismasi. Uluslararasi Turk Egitim Bilimleri Dergisi (UTEB), 4(7), 119-130 .

Kardas, M. N. \& Ozturk, Y. (2015). Aktif ogrenme tekniklerinin Turkce ogretiminde basari, tutum ve uygulamalara yonelik ogrenci gorusleriyle iliskisi: Bir meta-analiz calismasi. International Journal of Languages' Educa-tion and Teaching UDES Ozel Sayisi, 1682-1692.

Katirci, E. (2010). Farkli coklu ortamlarin ogrencilerin mekanik konusundaki kavram yanilgilarinin giderilmesine ve bilissel yuklenmelerine etkilerinin incelenmesi: Gorsel uzamsal zekâ boyutunda bir analiz. (Unpublished Master's Thesis). Marmara University, Istanbul.

Kavak, N., \& Koseoglu, F. (2007). Yapilandirici ogrenme yaklasimina dayali rol oynama ogretim yonteminin avantaj ve dezavantajlari. Gazi Universitesi Gazi Egitim Fakultesi Dergisi, 27(2), 309-325.

Kilic, E. (2006). Coklu ortamlara dayali ogretimde paralel tasarim ve gorev zorlugunun universite ogrencilerinin basarilarina ve bilissel yuklenmelerine etkisi. (Unpublished Doctoral Dissertation). Ankara University, Ankara.

Kirk, J. \& Miller, M. L. (1986). Reliability and validity in qualitative research. Ca: Sage.

Kirmizi, F. S. \& Akkaya, N. (2009). Turkce ogretimi programinda yasanan sorunlara iliskin ogretmen gorusleri. Pamukkale Universitesi Egitim Fakultesi Dergisi, 25, 42-54.

Kong, S. C. (2014). Developing information literacy and critical thinking skills through domain knowledge learning in digital classrooms: An experience of practicing flipped classroom strategy. Computers \& Education, 78, 160-173. http://dx.doi.org/10.1016/j.compedu.2014.05.009.

Lage, M. J., Platt, G. J. \& Treglia, M. (2000). Inverting the classroom: A gateway to creating an inclusive learning environment. The Journal of Economic Education, 31(1), 30-43.

Lai, C. L., \& Hwang, G. J. (2016). A self-regulated flipped classroom approach to improving students' learning performance in a mathematics course. Computers \& Education, 100, 126-140. https:// doi.org/10.1016/j.compedu.2016.05.006.

Lea, S. J., Stephenson, D. \& Troy, J. (2003). Higher education students' attitudes to student centered learning: Beyond 'educational bulimia'. Studies in Higher Education, 28(3), 321-334.

Michaelsen, L. K., Davidson, N. \& Major, C. H. (2014). Team-based learning practices and principles in comparison with cooperative learning and problem-based learning. Journal on Excellence in College Teaching, 25(3\&4), 57-84.

Millis, B. J. (2010). Promoting deep learning. IDEA paper, 47.

Mills, G. E. (2003). Action research: A guide for the teacher researcher. New Jersey: Prentice-Hall.

Mo, J., \& Mao, C. (2017). An empirical study on the effectiveness of college English reading classroom teaching in the flipped classroom paradigm. Revista de la Facultad de Ingenieria, 32(10), 632-639.

Moran, C. M. (2014). Changing paradigms: A mixed methods study of flipping the English language arts classroom. (Unpublished Doctoral Dissertation), North Carolina State University. 
Moran, C. M. (2018). “Just Don't Bore Us To Death”: Seventh graders' perceptions of flipping a technologymediated English language arts unit. Middle Grades Review, 4(1), 1-17.

Moran, C., \& Young, C. A. (2015). Active learning in the flipped English language arts classroom. In Curriculum Design and Classroom Management: Concepts, Methodologies, Tools, and Applications (pp. 588-609). IGI Global.

Murphy, S. H. (2009). Real authentic learning. Principal Leadership, 9(6), 6-8.

O'Neill, G. \& McMahon, T. (2005) Student-centered learning: What does it mean for students and lecturers?. O’Neill, G., Moore, S., McMullin, B. (Eds.) In Emerging Issues in the Practice of University Learning and Teaching. Dublin: AISHE.

O'Flaherty, J., \& Phillips, C. (2015). The use of flipped classrooms in higher education: A scoping review. The internet and higher education, 25, 85-95.

Ongoz, S., Aydin, S. \& Aksoy, D. A. (2016). Turkiye'de Egitim Bilimleri alaninda yapilan coklu ortam konulu lisansustu tezlerin egilimleri. Journal of Instructional Technologies \& Teacher Education, 5(1), 45-58.

Oral, B. (2008). The evaluation of the student teachers' attitudes toward Internet and democracy, Computers \& Education, 50, 437-445.

Ornstein, C. A., \& Hunkins, P. F. (2016). Curriculum: foundations, principles and issues. USA: Pearson.

Ozdemir, O. \& Acik, F . (2019). Development of written expression skills with Flipped Learning instruction: An embedded mixed method study. Hacettepe University Journal of Education, 34(4), 1075-1091. https://doi.org/10.16986/HUJE.2019048710.

Ozdemir, O. (2017). Turkce ogretiminde dijital teknolojilerin kullanimi ve bir web uygulamasi ornegi. Electronic Turkish Studies, 12(4), 427-444.

Pasisis, G. (2015). The flipped reading block: Making it work. New York: Scholastic.

Peregoy, S., \& Boyle, O. (2012). Reading, writing and learning in ESL: A resource book for teachers. New York: Allyn \& Bacon.

Rogers, P. L. (2001). Designing instruction for technology enhanced learning. London: IRM.

Rossi, R. D. (2014). Improving student engagement in organic chemistry using the inverted classroom model. Paper presented at 2014 Spring ConfChem: Flipped Classroom Online. Retrieved March 10, 2021 from the World Wide Web: http://confchem.ccce.divched.org/2014SpringConfChemP7.

Sahin, D. \& Bayramoglu, C. D. (2016). 2015 Turkce ogretim programinin metin tur ve tema secimi bakimindan degerlendirilmesi. Turkish Studies, (Prof. Dr. Hayati Akyol Armagani), 11(3), 20952130. http://dx.doi.org/10.7827/TurkishStudies.9289.

Saitta, E., Morrison, B., Waldrop, J. B., \& Bowdon, M. A. (2016). Introduction: Joining the flipped classroom conversation. In Best Practices for Flipping the College Classroom (pp. 1-16). Routledge.

Samuel, M. L. (2019). Flipped pedagogy and student evaluations of teaching. Active Learning in Higher Education, 24, 10. https://doi.org/10.1177\%2F1469787419855188.

Sever, S. (2011). Turkce ogretimi ve tam ogrenme. Ankara: Ani.

Sonnenwald, D. H. \& Li, B. (2003). Scientific collaboratories in higher education: exploring learning style preferences and perceptions of technology. British Journal of Educational Technology, 34(4), 419431.

Talan, T., \& Gulsecen, S. (2019). The effect of a Flipped Classroom on students' achievements, academic engagement and satisfaction levels. Turkish Online Journal of Distance Education, 20(4), 31-60.

Taskaya, S. M. \& Musta, M. C. (2008). Sinif ogretmenlerinin Turkce ogretim yontemlerine iliskin gorusleri. Elektronik Sosyal Bilimler Dergisi, 7(25), 240-251.

Temizyurek, F. \& Unlu, N. A. (2015). Dil ogretiminde teknolojinin materyal olarak kullanimina bir ornek: "Flipped classroom". Bartin Universitesi Egitim Fakultesi Dergisi, 4(1), 64-72. 
Tosun, N. (2017). Implementation of web 2.0-supported flipped learning in the learning management systems course: An experience from Turkey. The Malaysian Online Journal of Educational Management (MOJEM), 12. https://doi.org/10.22452/mojem.vol6no1.1.

Tunagur, M., Kardas, N., \& Kardas, M. (2021). The effect of student centered listening/speaking activities on turkish listening speaking skills of bilingual students. International Journal of Education and Literacy Studies, 9(1), 136-149. Doi: http://dx.doi.org/10.7575/aiac.ijels.v.9n.1p.136.

Turan, Z. \& Goktas, Y. (2015). Yuksekogretimde yeni bir yaklasim: Ogrencilerin ters yuz sinif yontemine iliskin gorusleri. Yuksekogretim ve Bilim Dergisi, 5(2), 156-164.

Turan, Z., \& Akdag-Cimen, B. (2019). Flipped classroom in English language teaching: A systematic review. Computer Assisted Language Learning, 1-17. https://doi.org/10.1080/09588221.2019.1584117.

Ulas, A. H. (2002). Klâsik donem soz ve anlam biliminin Turkce ve edebiyat ogretiminde fonksiyonel kullanimi. (Yayimlanmamis doktora tezi), Ataturk Universitesi, Erzurum.

Ulubey, O. \& Toraman, C. (2015). Yaratici drama yonteminin akademik basariya etkisi: Bir meta-analiz calismasi. Mustafa Kemal Universitesi Sosyal Bilimler Enstitusu Dergisi, 12(32), 195-220.

Ural, A. \& Ulper, H. (2013). Ilkogretim matematik ogretmeni adaylarinin matematiksel modelleme ile okudugunu anlama becerileri arasindaki iliskinin degerlendirilmesi. Kuramsal Egitimbilim Dergisi, 6(2), 214-241.

Varisoglu, B., Sahin, A. \& Goktas, Y. (2013). Turkce egitimi arastirmalarinda egilimler. Kuram ve Uygulamada Egitim Bilimleri, 13(3), 1767-1781.

Wang, Y., Huang, X., Schunn, C. D., Zou, Y., \& Ai, W. (2019). Redesigning flipped classrooms: a learning model and its effects on student perceptions. Higher Education, 78(4), 711-728. https://doi. org/10.1007/s10734-019-00366-8.

Yagmur Sahin, E., Kana, F. \& Varisoglu, B. (2013). Turkce egitimi bolumlerinde yapilan lisansustu tezlerin arastirma egilimleri. International Journal of Human Sciences, 10(2), 356-378.

Yildirim, A. \& Simsek, H. (2008). Sosyal bilimlerde nitel arastirma yontemleri. Ankara: Seckin.

Yuan, C. \& Moran, C. M. (2018). Flipped Classroom in China: Design, practice, and implications. In Digital Transformation and Innovation in Chinese Education (pp. 119-135). IGI Global. https:// doi.org/10.4018/978-1-5225-2924-8.ch007.

Zulfikar, H. (2011). Turkcenin anlatim gucu uzerine degerlendirmeler. Turk Dili, 713, 387-399. 


\section{APPENDIX}

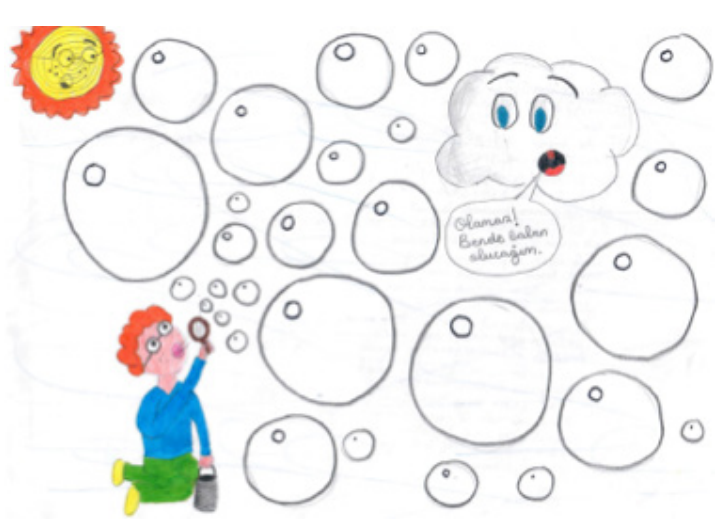

Picture 1. Examples of Student's Activities
Activity K: Visual preparation and visual expression

(When the cloud arrived, he saw a child. He was a guy with glasses and curly hair. He had a bubble tube and made bubbles. While some bubbles were as small as ants, some of them were as big as the sun. the cloud was very worried when he saw these bubbles because he thought he'd be sentenced in a balloon. That was the kid's purpose. The boy made a balloon as big as the cloud. The cloud just wanted to escape. He's barely curling through the bubbles. The child was very upset and cried. As the child cried, the bubbles grew twice more. The cloud saw this situation and took the child and put him in the bubble. They flied around the sky and had fun together.)
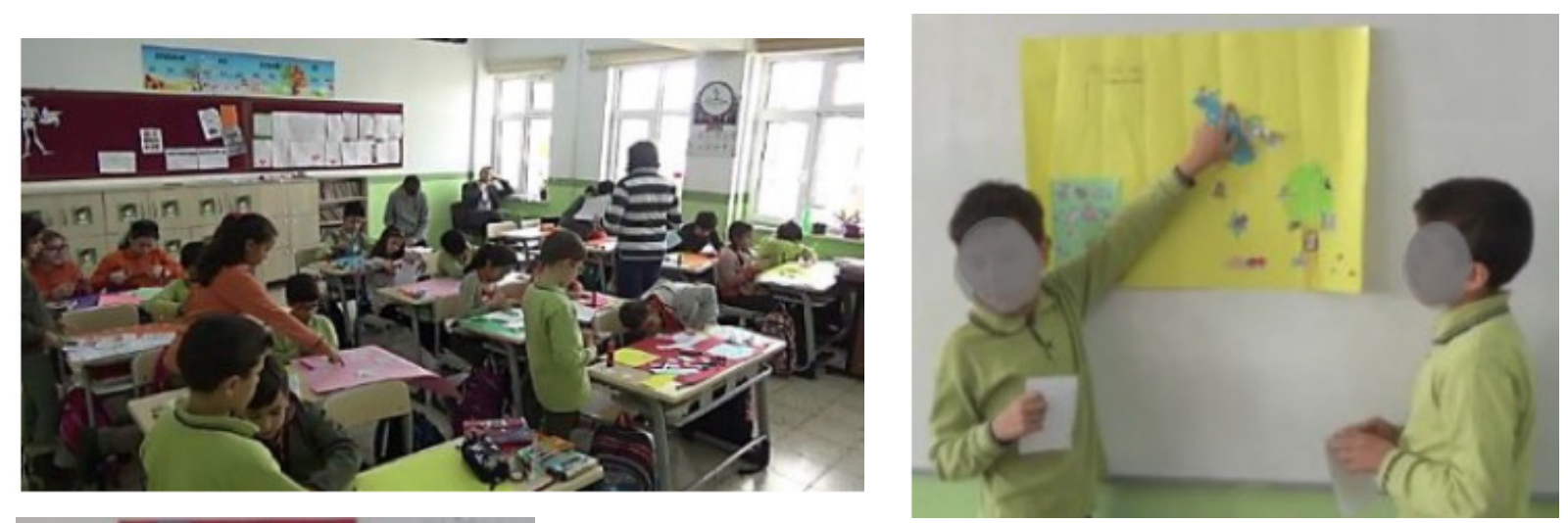
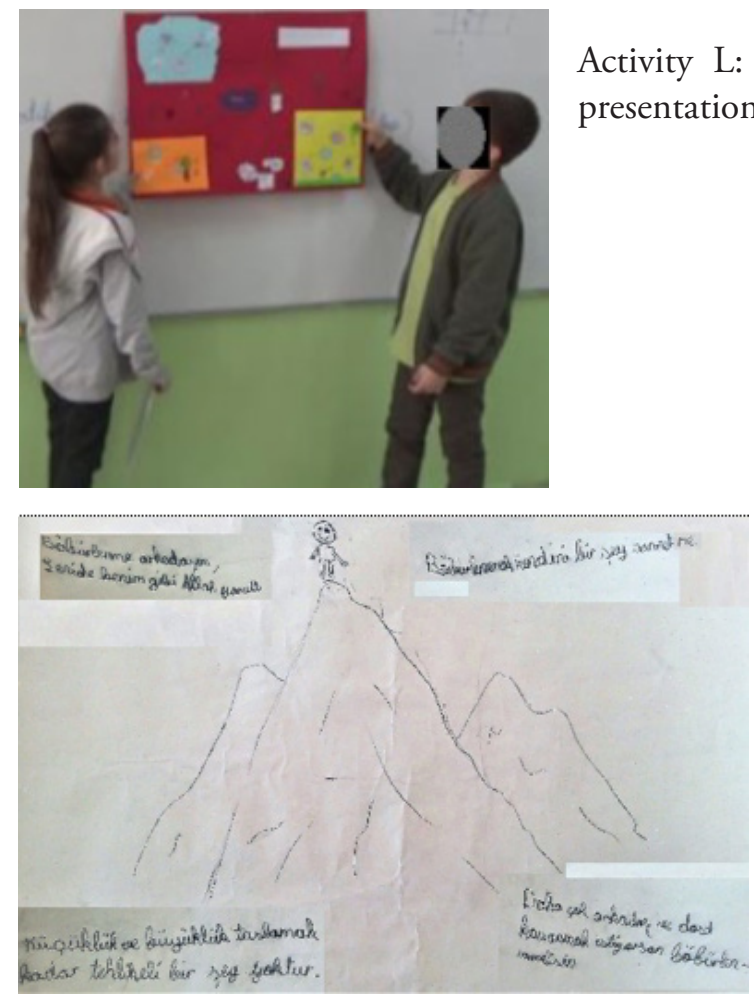

Activity F: Poster works (Do not boast dear friend. We are all created by Allah. There is nothing dangerous as much as riding a high horse. Do not boast, if you want to win more friends.)
Activity L: Visual creation and written expression (creation and presentation of national park project)

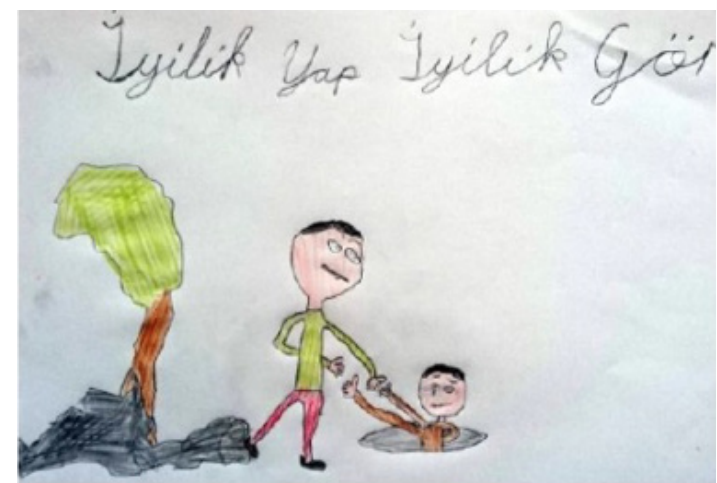

Activity A (slogan and visual creation): "Do good things and good things will happen to you" 


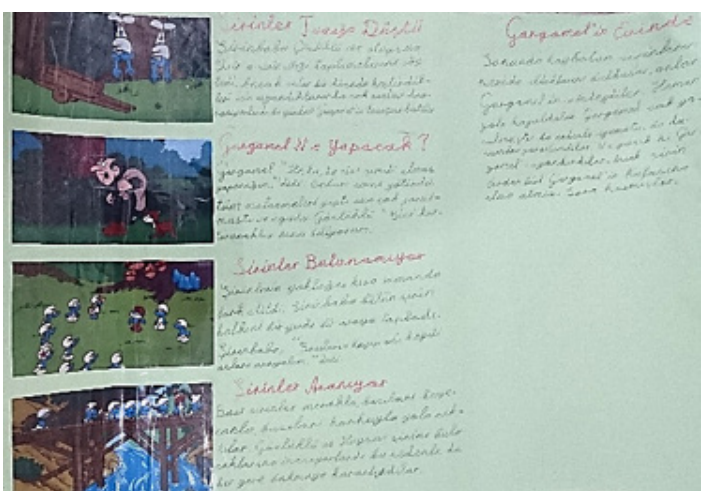

Activity G: Writing (Creating stories by sorting images)

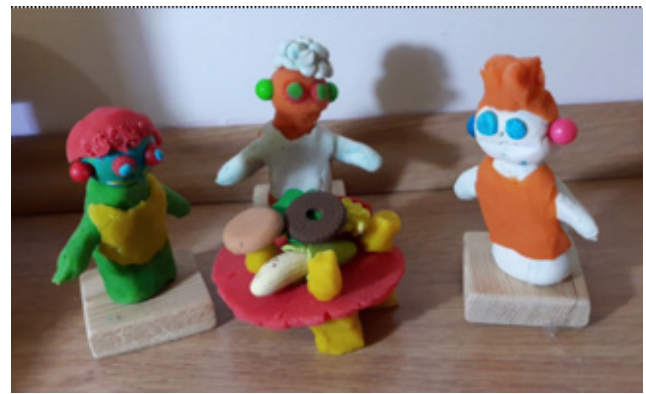

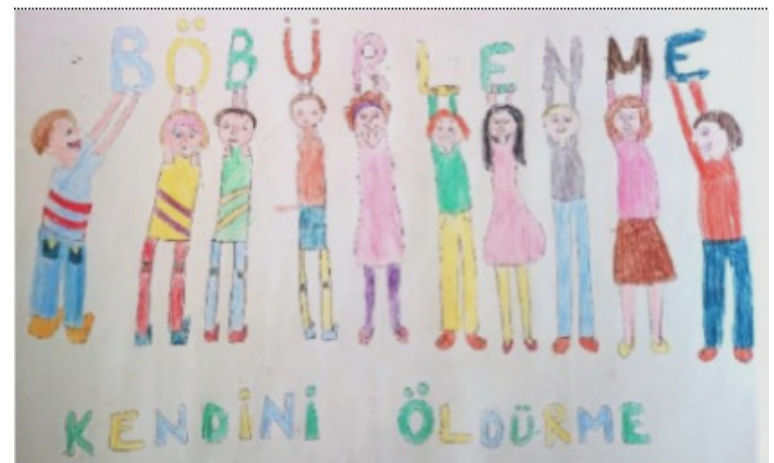

Activity F: Poster work (Do not boast, Do not commit suicide)

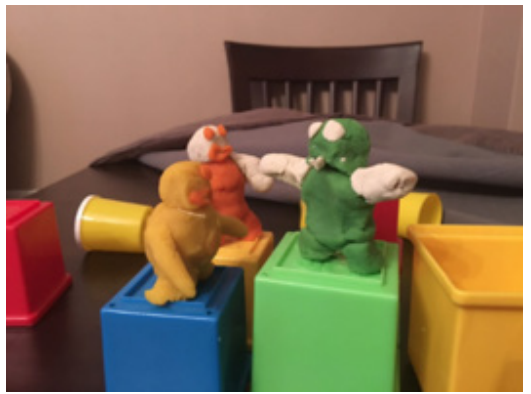

Activity F: Creating a digital story with play doughs

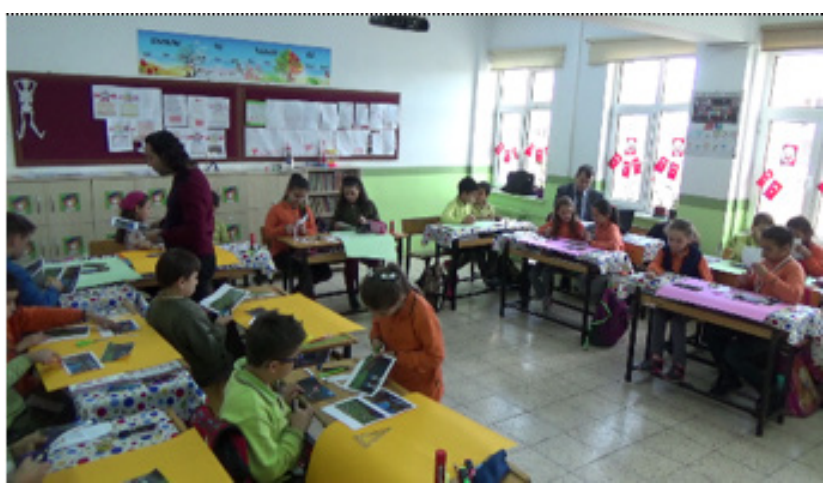

Activity C: Group activity (writing and visual presentation)

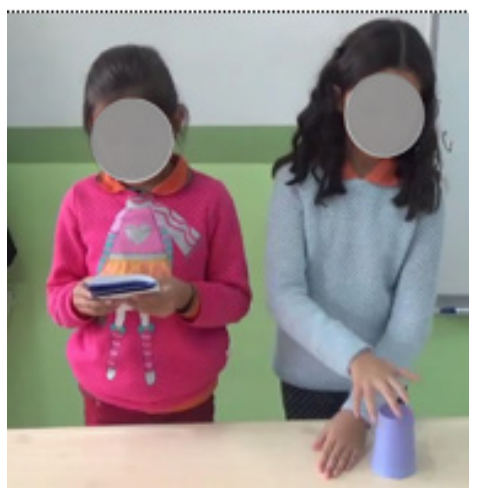

Activity J: Cup game (composing a song)

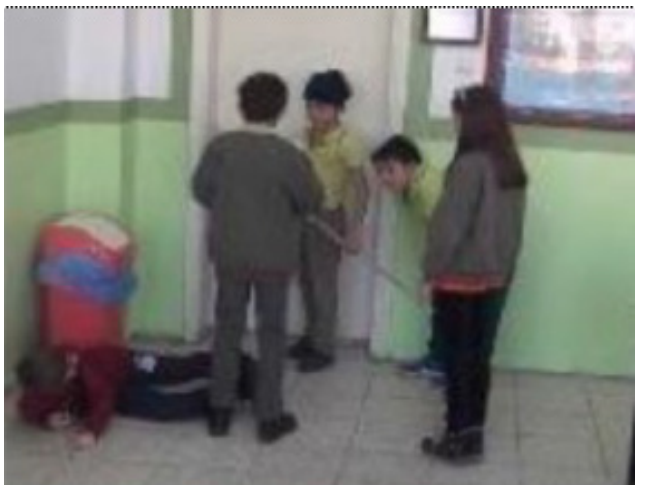

Activity C: Role-playing activity
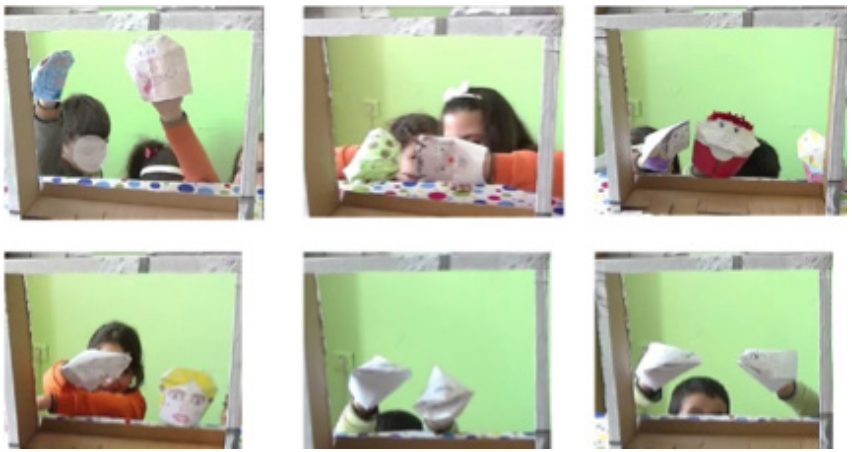

Activity D: Puppet Theatre 